Jurnal Bisnis dan Manajemen, Volume 22, No. 2, September 2021, p. 97-126

\title{
HALAL TOURISM RESEARCH EVALUATION IN 10 YEARS: PAST, PRESENT, AND FUTURE
}

\author{
Sherly Artadita1, Hisyam Hisyam² \\ ${ }^{1}$ Universitas Telkom, Indonesia \\ ${ }^{2}$ National Taiwan University of Science and Technology, Taiwan
}

\begin{abstract}
The growing Muslim population worldwide entice many countries to rule the burgeoning halal market, including the tourism sector. With its potential in reshaping the global tourism industry, researchers have been investigating key aspects that may smooth the operations of this unique tourism practice. In line with that, this study aims to analyze the research progress of halal tourism published from 2011 to 2020, summarize the identified key themes and issues, and suggest for future research area in halal tourism. In doing so, qualitative approach combining the bibliometric analysis, network analysis, and content analysis was employed to examine prior research on 'halal tourism' obtained from 'Scopus' database. VOSviewer and Microsoft Excel software are employed to process a total of 230 peerreviewed articles, carefully selected based on relevant query and context, such as years, document type, country, journal's name, authors' name, number of authors, and the keywords that frequently used by authors. The major finding of this study is the disclosure of keywords connection which grouping into three various clusters. These three clusters have their own prime keyword, namely Islamic tourism, tourism, and halal tourism. The overall analysis and the summary in this study is designed to provide insights that help researchers to design future halal tourism research agenda. As for the practitioners, this article could be a reference that may help them to have better understanding of the development, issues, and possible solutions related to the implementation of halal tourism.
\end{abstract}

Keywords: halal tourism, VOSviewer, bibliometric.

\section{EVALUASI RISET PARIWISATA HALAL DALAM 10 TAHUN: DULU, KINI, DAN NANTI}

\begin{abstract}
ABSTRAK
Pertumbuhan populasi Muslim di seluruh dunia menarik banyak negara untuk menguasai pasar halal yang sedang berkembang, termasuk sektor pariwisata. Dengan potensinya dalam membentuk kembali industri pariwisata global, para peneliti telah menyelidiki aspek-aspek kunci yang dapat memperlancar operasi praktik pariwisata yang unik ini. Sejalan dengan hal tersebut, tujuan dari penelitian ini adalah untuk menganalisis kemajuan penelitian pariwisata halal yang ada antara tahun 2011 hingga 2021, merangkum tema dan masalah utama yang teridentifikasi, dan memberikan saran untuk penelitian di masa depan dalam hal pariwisata halal. Dalam melakukannya, pendekatan kualitatif yang menggabungkan analisis bibliometrik, analisis jaringan, dan analisis konten digunakan untuk menguji penelitian sebelumnya tentang 'pariwisata halal' yang diperoleh dari database 'Scopus'. Penggunaan perangkat lunak VOSviewer dan Microsoft Excel digunakan untuk memproses total 230 artikel peer-review yang dipilih dengan cermat berdasarkan kueri dan konteks yang relevan, seperti tahun, jenis dokumen, negara, nama jurnal, nama penulis, jumlah penulis, dan kata kunci yang sering digunakan oleh penulis. Temuan utama dari penelitian ini adalah pengungkapan koneksi kata kunci yang dikelompokkan menjadi tiga kelompok yang berbeda. Ketiga kelompok ini memiliki kata kunci utamanya masing-masing, yaitu pariwisata Islami, pariwisata, dan pariwisata halal. Analisis keseluruhan dan ringkasan dalam penelitian ini dirancang untuk memberikan wawasan yang membantu para peneliti untuk merancang agenda penelitian pariwisata halal di masa depan. Bagi praktisi, artikel ini dapat menjadi referensi yang membantu mereka untuk lebih memahami perkembangan, isu, dan solusi yang memungkinkan terkait dengan implementasi pariwisata halal.
\end{abstract}

Kata-kata Kunci: pariwisata halal, VOSviewer, bibliometrik.

Korespondensi: Sherly Artadita, S.T.P., M.B.A., M.S.M. Business Administration Study Program, School of Communication and Business, Telkom University. Jln. Telekomunikasi Terusan Buah Batu Bandung 40257- Jawa Barat, Indonesia. Email: sherlyartadita@telkomuniversity.ac.id.

Submitted: July 2021, Accepted: August 2021, Published: September 2021

ISSN: 1412 - 3681 (printed), ISSN: 2442 - 4617 (online), Website: http://journal.feb.unpad.ac.id/index.php/jbm 


\section{INTRODUCTION}

The large number of Muslim population, that projected to reach 2.2 billion people by 2030 , become one of Islamic economy core drivers (DinarStandard, 2019). According to Global Islamic Economy Indicator (GIEI) Report 2019/20, Islamic economy defined as 'sectors whose core products/services are structurally affected by Islamic ethics and law'. The Islamic economy covers food, finance, travel, fashion, pharmaceuticals, cosmetics, and media \& entertainment. The spending of 1.9 billion Muslims is 2019 is estimated reach $\$ 2.88$ trillion in Islamic finance assets and \$2.02 trillion across six sectors, to be precise $\$ 1.17$ trillion in Halal food sector, \$277 billion in modest fashion sector, $\$ 222$ in media \& recreation sector, \$194 billion in Muslim-friendly travel, \$94 billion in pharmaceutical sector, $\$ 66$ billion in cosmetics (DinarStandard, 2020).

The Islamic economy market size grows along with the projected growth of Muslim population due to the obligation that bind Muslim to comply with halal requirements for every aspect in their life. The word 'halal' itself originally is Arab language with the meaning acceptable, permitted, allowable, and/or permissible (El-Gohary, 2016). As Muslimfriendly travel is one of the sectors that should comply with halal requirements, the concept of Halal tourism is a form of offerings that perfectly suitable to accommodate Muslim customers who expect their travelling experience will comply with Sharia or Islamic law. Sharia is referring to 'the divine rules and regulations that order humanity and all interactions with other creatures' (Rasul, 2019). This concept pointed that, while travelling either to major populated Muslim or non-Muslim countries, the requirements of Muslim tourists, which is practically ranging from the availability of halal food, accessible prayer room, an accommodation with segregated swimming pool, and other amenities, should be available to support them to live according to the God's provision.

Nowadays, both Muslim and non-Muslim countries are trying to create Muslim-friendly travel destinations. In 2019, 130 destinations from the Organization of Islamic Cooperation (OIC) and the non-OIC countries participated in the Global Muslim Travel Index (GMTI), with four factors being evaluated, namely access, communications, environment, and services. The result placed Malaysia and Indonesia in the first position with the total score 78 . Followed by Turkey, Saudi Arabia, and United Arab Emirate in third until fifth position, with total score 75, 72, and 71, respectively. In sixth position, Qatar beat Morocco with slight point (68 vs 67). Then, both Bahrain and Oman got 66 points, make them placed in the eighth position. Interestingly, Brunei, which is categorized as OIC destination, share same rank with Singapore in $10^{\text {th }}$ position with total score 65 . This situation indicates that the non-OIC destination could create Muslim- 
Jurnal Bisnis dan Manajemen, Volume 22, No. 2, September 2021, p. 96-126

friendly tourism or halal tourism as good as the OIC destination.

Many studies related to halal tourism already done by the researchers. In 2019. Rasul (2019), conducted a systematic review of 27 articles related to halal tourism, that published from January 2008 until January 2018, to unveil the concept, principles, impact, scope, trends, opportunities, and challenges of this sector. As success and positive potential comes hand in hand with the opportunity and challenges of halal tourism, this study is attracted to map the trend of existing halal tourism related literatures by identifying several aspects, such as the year of publication, the type of document, the country origin, the name of journal and authors, also the keywords that frequently used by the author. From such information, this study is designed to suggest the possible foundations or major research hotspots that could alleviate future halal tourism research agenda, which later will answer the challenge and opportunity in halal tourism sector.

From this point forward, this paper is arranged to define the research methodology that occurred after the above information were settled. The process of data collection and data analysis also introduced in this section. Then, this study provides the interpretation and discussion for the result of analysis, starts with the descriptive statistics and followed with the network analysis of the bibliometric data. Finally, the conclusion that sums up all the research agenda of this paper are set forth in the last section.

\section{LITERATURE REVIEW}

Halal tourism is relatively a new breakthrough concept in tourism sector and has a great potential to grow due to the increasing Muslim population worldwide. Halal is an Arabic word means 'permissible', which refers to object or action that is allowed by Sharia (the provisions of Allah SWT and Hadith of Prophet Muhammad) and should be fulfilled to show an obligation towards Islamic faith (Asnawi, Sukoco, \& Fanani, 2018; Shah Alam \& Mohamed Sayuti, 2011), including in tourism or travel activity.

Until now, the definition of Halal tourism is still diverse. Mohsin, Ramli, \& Alkhulayfi (2016) defined halal tourism as the product or service in tourism that conformed Muslim travelers' need, including dietary requirement and worship based on Islamic teaching. Halal tourism also cover all travel related activities of a Muslim tourist that are acceptable and permissible according to Islamic law (Battour \& Ismail, 2016; Harahsheh, Haddad, \& Alshorman, 2019). Halal tourism also act as a novel business model innovation in tourism sector that provides Muslims customers with holiday opportunities that conducted in accordance with Islamic principles (Yagmur, Ehtiyar, \& Aksu, 2020). From several definitions above, it can be concluded that Halal tourism is referring to any tourism products and services (e.g. accommodation, food, attitude, clothing) that in accordance with Islamic law and meet the need of Muslim tourist.

Since 2011, CrescentRating evaluated several destinations and rank them based on their 
Jurnal Bisnis dan Manajemen, Volume 22, No. 2, September 2021, p. 96-126

quality in serving Muslim traveler, and in 2015, Mastercard-CrescentRating Global Muslim Travel Index (GMTI) was introduced as an Index that can help to benchmark the destination on Muslim Travel Market (MastercardCrescentRating, 2017). At first, the criteria that used in GMTI 2015 and 2016 comprise three area (Table 1). But since 2017, GMTI use ACES framework that cover four area - Access, Communication, Environment, and Services.
This model almost always updated, in terms of its sub-criteria (Table 2). The areas in each of GMTI, as presented in Table 1 and Table 2, is evolved. Special for GMTI 2021, 'visa requirement' and 'unique experiences' are not used in the ranking evaluation because of certain consideration. This evolution of criteria that being used in GMTI indirectly imply that the need of Muslim and the condition of travel market always change over the year.

Table 1. Criteria in GMTI 2015 and GMTI 2016

GMTI 2015

Suitability as a holiday destination, family friendliness, and Safety

Areas

Muslim friendly services and facilities available at the destination

Halal awareness and reach out to Muslims by the destination
GMTI 2016

Family-friendly holiday and safe travel destination Muslim-friendly services and facilities at the destination

Halal awareness and destination marketing

Source: Mastercard-CrescentRating $(2015,2016)$.

Table 2. Criteria in GMTI 2017, 2018, 2019, and 2021

\begin{tabular}{|c|c|c|c|c|}
\hline Areas & GMTI 2017 & GMTI 2018 & GMTI 2019 & GMTI 2021 \\
\hline \multirow{3}{*}{ Access } & Visa requirements & Visa requirements & Visa requirements & Visa requirements \\
\hline & Air connectivity & Air connectivity & Connectivity & Connectivity \\
\hline & & Transport Infrastructure & Transport Infrastructure & Transport Infrastructure \\
\hline \multirow{3}{*}{ Communication } & $\begin{array}{l}\text { Muslim traveler needs } \\
\text { awareness \& outreach }\end{array}$ & Outreach & Outreach & Destination marketing \\
\hline & Ease of communication & Ease of communication & Ease of communication & $\begin{array}{l}\text { Communication } \\
\text { proficiency }\end{array}$ \\
\hline & & Digital Presence & Digital Presence & Stakeholder awareness \\
\hline \multirow{4}{*}{ Environment } & $\begin{array}{l}\text { Family-friendly } \\
\text { destination }\end{array}$ & Safety \& culture & Safety & Safety \\
\hline & Muslim visitor arrivals & Visitor arrivals & Visitor arrivals & Visitor arrivals \\
\hline & Muslim traveler \& & Enabling climate & Enabling climate & Enabling climate \\
\hline & general safety & & Faith restriction & Faith restriction \\
\hline
\end{tabular}


Jurnal Bisnis dan Manajemen, Volume 22, No. 2, September 2021, p. 96-126

\begin{tabular}{|c|c|c|c|c|}
\hline Areas & GMTI 2017 & GMTI 2018 & GMTI 2019 & GMTI 2021 \\
\hline \multirow{4}{*}{ Services } & $\begin{array}{l}\text { Dining options \& halal } \\
\text { assurance }\end{array}$ & $\begin{array}{l}\text { Core needs (halal food \& } \\
\text { prayers) }\end{array}$ & $\begin{array}{l}\text { Core needs (halal food \& } \\
\text { prayer facilities) }\end{array}$ & $\begin{array}{l}\text { Core needs (halal food } \\
\& \text { prayer facilities) }\end{array}$ \\
\hline & Access to prayer places & $\begin{array}{l}\text { Core services (hotel, } \\
\text { airports) }\end{array}$ & $\begin{array}{l}\text { Core services (hotel \& } \\
\text { airports) }\end{array}$ & $\begin{array}{l}\text { Core services (hotel \& } \\
\text { airports) }\end{array}$ \\
\hline & Airport facilities & Unique experiences & Unique experiences & Unique experiences \\
\hline & Accommodation options & & & \\
\hline
\end{tabular}

Source: Mastercard-CrescentRating (2017, 2018, 2019, 2021).

The first area that need to be considered while creating halal tourism is accessibility, which not only refer to physical access (e.g., road, bridge, airport, etc.), but also refer to the policies (e.g., visa requirement). One of the prove of accessibility effect toward halal tourism is shown by the number of Muslim tourist who came from Malaysia and Indonesia to Japan in 2014 that increased (i.e., $41.3 \%$ and $16 \%$, respectively) due to Yen value reduction and visa requirement easiness for Malaysian and Indonesian in entering Japan (Samori, Md Salleh, \& Khalid, 2016).

Next area is communication, that emphasizing on the destination marketing in interacting with Muslim tourist and the awareness of halal tourism stakeholders. The revolution of technology changes the way of tourist in search, book, also experience their travel (COMCEC Coordination Office, 2018). Thus, the easiness to access the information about certain halal tourism destination become an important thing. For example, the provision of information about prayer time and worship places (e.g., Mosque, prayer room) around tourist attractions, which can be found in guidebook or other information source (e.g., mobile application), will make it easier for Muslim to conduct five-times routine prayer (i.e., Fajr, Dhuhr, Asr, Maghrib, Isha prayer) in a day.

The third area is environment, which covering the safeness during traveling and the situation which support Muslim tourist to act according to their faith. During traveling, the safety assurance become the main consideration. Islamophobia which portrayed by international media become the cause of Muslim tourist insecurity and their perception of risk during traveling to other country (Nik Ramli Nik Abdul Rashid, Chutima Wangbenmad, \& Kamarul Ariffin Mansor, 2021). Thus, in this situation, the credible halal tourism is the one which could provide safety and comfort destination. Along with those notion, Wingett \& Turnbull (2017) pointed that the opportunity to 'living Islam' (e.g., could hear azan/call to prayer, could pray, also having fun but halal) also protecting the children from bad behavior and alcohol become the expectations of Muslim tourist during their holiday. Similar notion also describe by Sriprasert, Chainin, \& Rahman (2014), that pointed the presence of Azan and the availability of Islamic financial service/banks become one 
Jurnal Bisnis dan Manajemen, Volume 22, No. 2, September 2021, p. 96-126

the strongest need of Muslim tourist in public area.

The last area is services, which highlighted the tourist experience during travelling to halal tourism. In this area, the potential problem could emerge from hotel services. Boğan \& Sarışık (2019) pointed that the stipulation of hotel business standard in halal tourism become the first priority that need to be fulfilled. As previously stated by El-Gohary (2016), the problem regarding hotel in halal tourism arise when the hotel provide the service that suitable for Muslim (e.g. provide halal food, modest dress code for the staff, segregation facilities, etc.), but in the same time they still provide non-Halal activities in their place, for example provide nonhalal food and alcohol to customer, offering nightclubs for non-Muslim customers, or have un-conservative TV channels. This situation actually become a dilemma for hotel providers, considering the differences of grading system in every country, the possibility that the hotel will serve non-Muslim customer, also the level of religiosity of Muslim tourist.

Here, the role of researchers is taken into account to unveil other potential challenges and solutions in halal tourism, which in the same time also supported by government and tourism providers to resolve the problem.

\section{METHODS}

This research use literature review methodology to explore existing research development related to halal tourism. Literature review was chosen because it has been known as a suitable approach to map out and evaluate the body of literature of a particular research area to inspire future research (Tranfield, Denyer, \& Smart, 2003).

Among several option of technique in literature review, bibliometric analysis, network analysis, and content analysis were chosen in this study to examine the linkage of halal tourism related articles. The research design of this study is shown in Figure 1. Moreover, the following research questions are drawn to guide the unfolding of existing knowledge and theories from research related to halal tourism that has been published to date.

RQ1. How is the distribution of the publication by genres?

RQ2. How is the growth of halal tourism research over time?

RQ3. What are the countries that majorly contribute to halal tourism research?

RQ4. What are the countries that have most citation to halal tourism research?

RQ5. Which journal holds most of the publication related to halal tourism?

RQ6. Which publication has the most citation in halal tourism research?

RQ7. What are the keywords that frequently used by authors in writing the halal tourism related publications?

RQ8. How is the connection between the keywords?

RQ9. What are the take home key for future halal tourism research? 


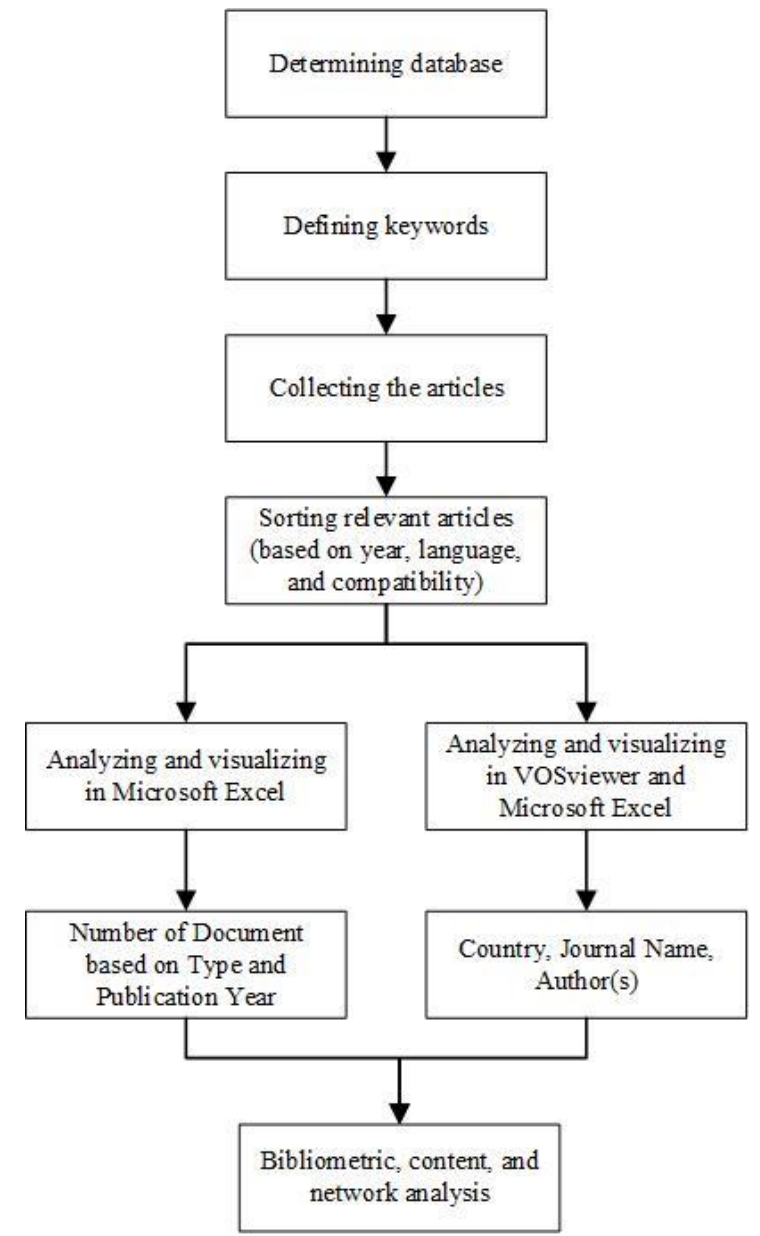

Figure 1. Research Design

Source: Processed data (2021)

To answer those questions, this study gathered the data mainly from secondary resource. Scopus database was chosen as a single database that is utilized in this study, with consideration that published articles in the journal which indexed by this database are credible. Moreover, prior researcher who conducted bibliometric study also claimed that Scopus database has a comprehensive journal collection compared with Web of Science (Chicksand, Watson, Walker, Radnor, \& Johnston, 2012; Mishra, Gunasekaran, Papadopoulos, \& Hazen, 2017). Also, Scopus database is known as a database for broader educational journal in social science, medicine, STEM, also art and humanities (Fahimnia, Tang, Davarzani, and Sarkis, 2015).

The data collection was done on June $13^{\text {th }}$, 2021. For the initial data collection, relevant keyword were set up. The final keyword is ' Halal tourism' OR 'Islamic tourism' OR 'Muslim tourism' OR 'Muslim friendly tourism' OR 'Islamic destination' OR 'Muslim destination' OR 'halal hosptality' OR 'Islamic hospitality' OR 'Muslim friendly hospitality'. Those article then downloaded in comma separated value 
(CSV) form. Because this research will analyze the trend of halal tourism publication, thus the latest of publication is in 2020, and the oldest is 2011. Article in 2021 was not chosen as the latest year of publication because the year is still going, thus there is a possibility that the whole picture of publication that published in that year could not be captured. Additionally, 10 years period of publication was chosen in order to grab spesific changes or unique phenomenon related to halal tourism publication during that period. We also ensure that all the articles is in English, to prevent any complexities of other language translation. Moreover, the documents with not clear or missing information, such as related to document title, year of publication, and journal name, are deleted. At the end, after the filtering process, 230 peer-reviwed articles were captured.

The data (in CSV form) then computed in Microsoft Excel and VOSviewer. VOSviewer is a software that developed by Leiden University's Centre for Science and Technology Studies, with the ability in constructing and viewing bibliometric maps (van Eck \& Waltman, 2010). This software was chosen because of its flexibility in collaborative research environment and its friendly interface to make bibliometric map with numerous features. For this study, we specifically use co-occurrence of keywords to align with the objectives that were set earlier. Moreover, according to Shaharudin et al. (2019), the use of VOSviewer has helped them to identify the research gaps based on the dataset in their study. The flaw of VOSviewer is on the analysis depth that not as flexible as in BibExcel, but it can be resolved by the assistance from Microsoft Excel.

The analysis of this study is focusing on the information of document type, publication year, country of publication, journal, authors, and title, which done fairly by using Microsoft Excel and VOSviewer. The interpretation of document types and the number of publications are processed using simple formula in Microsoft Excel. Meanwhile, the interpretation of other details such as number of publication and citation based on country, journal name, and authors were firstly computed in VOSviewer. After that, the relevant data were saved into CSV format file, then cleaned and arranged in Microsoft Excel. Meanwhile, we choose co-occurrence of authors keyword feature in VOSviewer software for network analysis. At the end the evaluation of emerging issue or themes was done by analyzed the content of articles in question, or referring to other research to obtain better explanation and deeper understanding.

\section{RESULTS AND DISCUSSION}

The first evaluation is regarding the number of publications based on document type (Table 3), with the purpose to find the researchers tendency in publishing their research related to halal tourism. Thus, to find a whole picture, no restriction of document type was set in initial setting. The result in Table 3 shown that seven different types of documents are existed. Among 
Jurnal Bisnis dan Manajemen, Volume 22, No. 2, September 2021, p. 96-126

them, 173 publications mainly published in article type (75.22\%).

Table 3. The Number of Document Based on

\begin{tabular}{lcc}
\multicolumn{3}{c}{ Type } \\
\hline Document Type & $\begin{array}{c}\text { Number of } \\
\text { Documents }\end{array}$ & \% \\
\hline Article & 173 & 75.22 \\
Conference Paper & 16 & 6.96 \\
Book Chapter & 20 & 8.70 \\
Review & 16 & 6.96 \\
Letter & 1 & 0.43 \\
Editorial & 2 & 0.87 \\
Book & 2 & 0.87 \\
\hline \multicolumn{1}{c}{ Total } & 230 & 100 \\
\hline
\end{tabular}

Source: Processed data (2021).

Those result similar with Yagmur, Ehtiyar, \& Aksu (2019) that found, out of 60 document that being evaluated, 27 publication (45\%) related to halal tourism which published in in "Web of Science Core Collection" database are in the form of article document type. This situation indicates that many researchers are more interested on publishing their research in article journal forms. So, there is a big chance for them to published their research in other forms, for example in book or chapter, which hopefully will be more accessed by the community and make them conscious of halal tourism existences.

Table 4. The Number of Document Based on Publication Year

\begin{tabular}{ccc}
\hline Publication Year & $\begin{array}{c}\text { Number of } \\
\text { Documents }\end{array}$ & \% \\
\hline 2020 & 73 & 31.74 \\
2019 & 37 & 16.09 \\
2018 & 34 & 14.78 \\
2017 & 24 & 10.43 \\
2016 & 23 & 10.00 \\
2015 & 8 & 3.48 \\
2014 & 13 & 5.65 \\
2013 & 4 & 1.74 \\
2012 & 10 & 4.35
\end{tabular}

\begin{tabular}{ccc}
\hline Publication Year & $\begin{array}{l}\text { Number of } \\
\text { Documents }\end{array}$ & \% \\
\hline 2011 & 4 & 1.74 \\
\hline Total & 230 & 100 \\
\hline
\end{tabular}

Source: Processed data (2021).

Table 4 depicted the distribution of halal tourism publications from 2011 until 2020. The number of publications fluctuated from 2011 until 2014 with the highest publication was 13 titles in 2014. But after the fall in 2015, the number of publications always increasing, with the peak 73 publications in 2020. It can be argued that studies related to halal tourism gained a popularity and become a new focus for researchers after 2015. Similar result also found in previous bibliometric analysis by Yagmur et al (2019), which found that the studies in halal tourism field is started in 2011 and increased year by years.

The increasing number of halal tourism research publication is inseparable from the growing number of Muslim populations globally, which taking a big part as a cause of halal market development. The total number of Muslim population around the world is about 1.8 billion in 2018, and their spending on Muslim-friendly travel was valued at \$189 billion (DinarStandard, 2019). Then, according to State of the Global Islamic Economy Report 2020/21, the consumers spending in Muslim-friendly travel is estimated reach $\$ 194$ billion in 2019 , and projected to growth up to $\$ 208$ billion in 2024 (DinarStandard, 2020). Seeing this progress, indicate the potential of halal tourism or Muslim-friendly tourism in 
Jurnal Bisnis dan Manajemen, Volume 22, No. 2, September 2021, p. 96-126

increasing GDP (Gross Domestic Product) of a nation.

Next, this research also examines the number of documents and citations based on countries. Table 2 shown that Malaysia and Indonesia are the leading countries for the number of halal tourism related publication from 2011 until 2020.

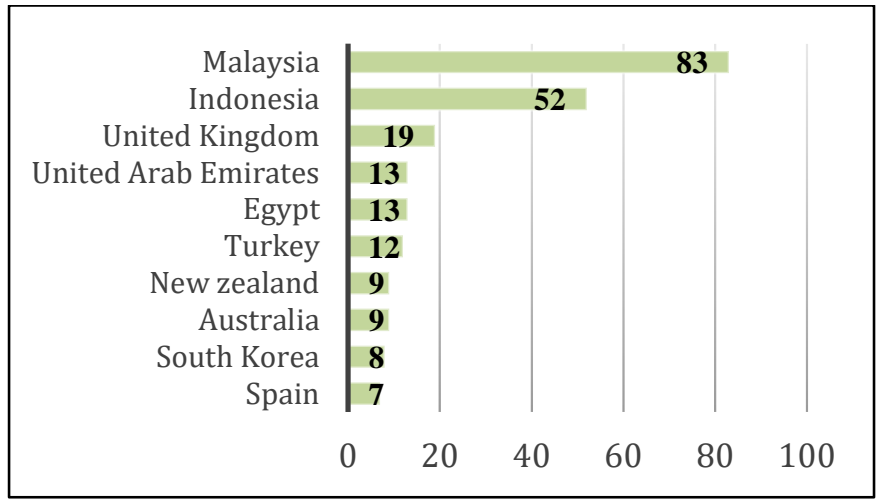

Figure 2. The Top 10 Country with The Highest Number of Document Publication in Halal Tourism from 2011-2021

Source: Processed data (2021).

From the top 10 countries with the highest number of publications listed in Figure 2, five countries are from Organization of Islamic Cooperation (OIC) countries (i.e. Malaysia, Indonesia, United Arab Emirates, Egypt, and Turkey) and the other five (i.e. United Kingdom, New Zealand, Australia, South Korea, and Spain) are non-OIC countries. This fact implies that halal tourism starts to immerse not only in country with Muslim majority but also in minority country. But still, research related halal tourism in the other country beside Malaysia and Indonesia is still scarce. This condition actually an opportunity for researchers to rigorously study the implementation of halal tourism in countries other than Malaysia and Indonesia so the international network of halal tourism around the globe can be established.

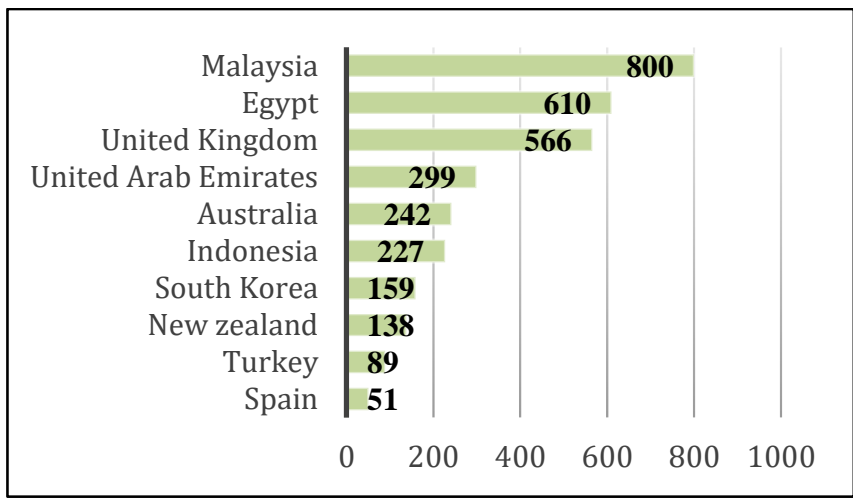

Figure 3. The Top 10 Citation of Halal Tourism Publication based on Country from 2011-2021 Source: Processed data (2021).

Furthermore, in Figure 2 and Figure 3, it shown that Malaysia is the leading country both for the number of document publication (83 articles) and the number of citation (800 articles). It implies Malaysia's positioning as a leading country in halal tourism sector. Malaysia always in the first place as the best destination for Muslim travelers based on the overall scores in four area (i.e. access, communications, environment, and services) of GMTI evaluation in 2015 until 2019, with the score $83.8,81.9,82.5,80.6$, and 78, respectively (Mastercard-Crescentrating, 2015, 2016, 2017, $2018,2019)$ Although there was an absenteeism of GMTI report in 2020, Malaysia prove its quality in halal tourism sector by taking the first place in GMTI 2021 with overall score 80 (MastercardCrescentRating, 2021).

With the total of 52 articles, Indonesia occupied the second place in the ranks of countries with the most halal tourism publications. Yet, Indonesia is on sixth position for the number of 
Jurnal Bisnis dan Manajemen, Volume 22, No. 2, September 2021, p. 96-126

citations (227 citation). The one that took the second place as the most cited publication based on country is Egypt (610 citations), followed by United Kingdom (566 citations), United Arab Emirates (299 citations), and Australia (242 citations).

The same evaluation also applied based on journal and authors category. In total, 230 documents are published in 110 Scopus indexed journals, that wrote by 547 authors. Figure 4 presented the top 10 journals with highest number of documents. Plainly, the Journal of Islamic Marketing (26 documents) dominating the stands. Meanwhile, Figure 5 presented the top 10 journals with the most citations, which lead by Tourism Management Perspective (597 citation) with their 14 documents. On the other hand, Journal of Islamic Marketing is in third position (as shown in Figure 5), with only 232 citations. This achievement is expected since the Tourism Management Perspective is a journal that mainly focus on travel and tourism.

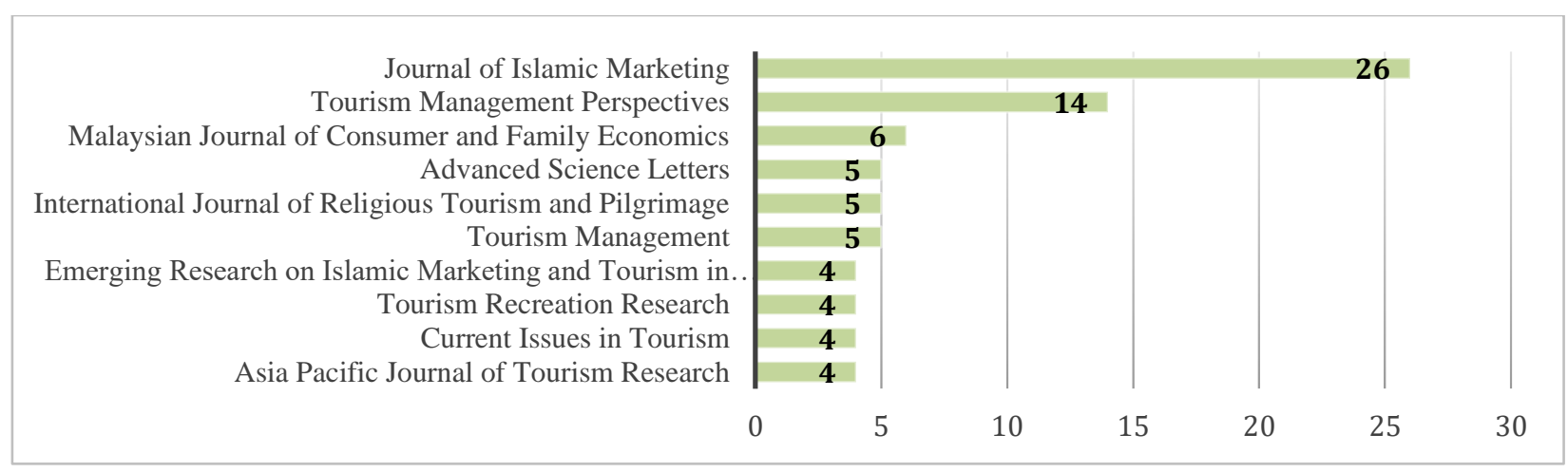

Figure 4. Top 10 Journals with The Most Number of Document in 2011-2020 for Halal Tourism Related Theme

Source: Processed Data (2021).

As stated in ScienceDirect (2021), "Tourism Management Perspective is an interdisciplinary journal concerned with the planning and management of travel and tourism, including tourist experiences and the consequences of those experience for communities, economies and environments. It is also concerned with the creation of image, the shaping of tourist experiences and tourist perceptions, and the ways in which tourist organizations manage themselves and destination”. Interestingly, four journals (i.e. Annals of Tourism Research, International Journal of Tourism Research, International Journal of Culture, Tourism and Hospitality Research, and Journal of Destination Marketing and Management) that not listed in Figure 3 could beat the number of citation of the other four journal (i.e. Malaysian Journal of Consumer and Family Economics, Advanced Science Letter, International Journal of Religious Tourism and Pilgrimage, also Emerging Research on Islamic Marketing and Tourism in The Global Economy) that previously is listed as the top 10 journal with the most number of document. 
Jurnal Bisnis dan Manajemen, Volume 22, No. 2, September 2021, p. 96-126

In this case, Annals of Tourism Research only has two documents but it cited 209 times. Moreover, International Journal of Tourism Research has three documents with 129 citations, International Journal of Culture, Tourism and Hospitality Research has four documents with 91 citations, and Journal of Destination Marketing and Management has three documents with 55 citations. This phenomenon indicates that higher number of documents does not guarantee more citation. Similar phenomenon also occurs in author category. Figure 6(a) present the top 10 most productive authors, which lead by that Han and Al-Ansi who have 7 documents. But, if we take a look to Figure 6(b), Battour who has six documents got the first place as the authors with the most citations (351 citations). This number is beat Han and Al-Ansi who got 158 citations.

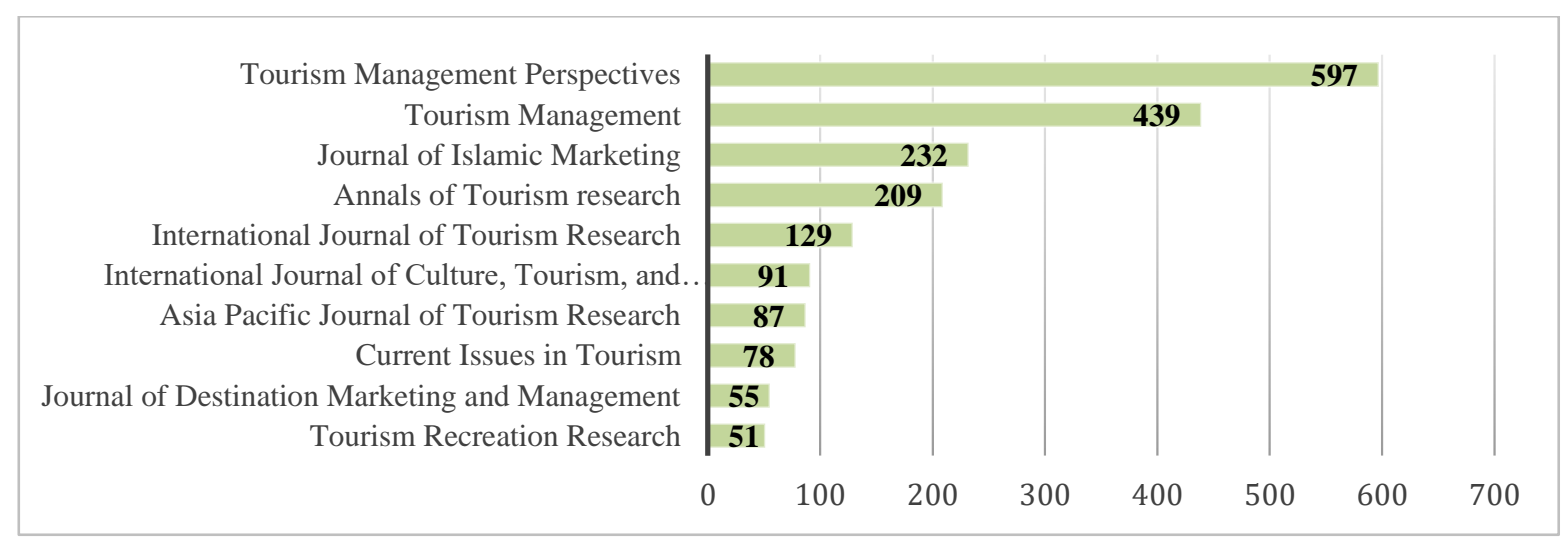

Figure 5. The Top 10 Citation of Halal Tourism Publication based on Journals Name from 2011-2020

Source: Processed data (2021).

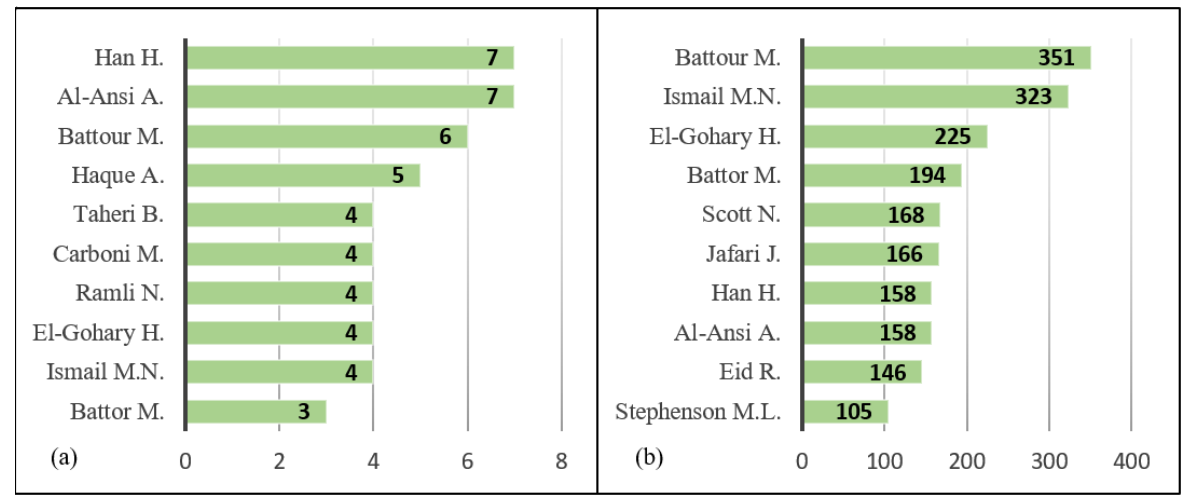

Figure 6. (a) The Top 10 Most Productive Author(s); (b) The Top 10 Most Cited Author(s) in Halal Tourism Publication based on Journals Name from 2011-2020 Source: Processed data (2021). 
Jurnal Bisnis dan Manajemen, Volume 22, No. 2, September 2021, p. 96-126

Table 5. The Top 10 Publication with The Most Number of Citation in 2011-2020

\begin{tabular}{|c|c|c|c|c|c|c|}
\hline No. & $\begin{array}{l}\text { Document } \\
\text { Title }\end{array}$ & Author(s) & $\begin{array}{c}\text { Number of } \\
\text { Citation }\end{array}$ & Aim/Purpose & Findings & Future Research \\
\hline 1. & $\begin{array}{l}\text { Muslim world } \\
\text { and its tourism }\end{array}$ & $\begin{array}{l}\text { Jafari \& } \\
\text { Scott } \\
(2014)\end{array}$ & 166 & $\begin{array}{l}\text { Urge the discussion related to } \\
\text { Islam and tourism with the } \\
\text { topic that involves religious } \\
\text { and secular issues. }\end{array}$ & $\begin{array}{l}\text { 1. The long journey of Islam expansion produces various } \\
\text { ways of development for tourism in Muslim world. } \\
\text { 2. The purpose of travelling for Muslim is diverse, it } \\
\text { might be for religious purpose or other purpose (e.g. } \\
\text { historical, cultural, and social meeting, learning } \\
\text { process, spread God's word, etc.). } \\
\text { 3. Traveling to non-Muslim countries is a challenge for } \\
\text { Muslim travelers, especially regarding the daily prayers } \\
\text { (e.g. prayer times, ablution facilities, prayer room), } \\
\text { halal status of food, and place to stay (i.e. hotel). } \\
\text { 4he challenge in developing tourism in Muslim } \\
\text { countries is lies on the marketing strategy, how to } \\
\text { attract non-Muslim travelers, issue related to politic, } \\
\text { and the women roles. }\end{array}$ & $\begin{array}{l}\text { The need of cooperative scholarly } \\
\text { research activity, that will unfold } \\
\text { several issues related to Islam and } \\
\text { tourism, such as the relationship } \\
\text { between religious tolerance with } \\
\text { tourism, the way of Islamic tourism } \\
\text { development in serving Western } \\
\text { tourist, the role of Islam and tourism } \\
\text { mixture in enhancing the number of } \\
\text { international tourist arrival in Muslim } \\
\text { countries, innovation in tourism } \\
\text { which mixture religious experience } \\
\text { and traditional pilgrimage with other } \\
\text { activity. }\end{array}$ \\
\hline 2. & $\begin{array}{l}\text { The role of } \\
\text { Islamic } \\
\text { religiosity on } \\
\text { the } \\
\text { relationship } \\
\text { between } \\
\text { perceived } \\
\text { value and } \\
\text { tourist } \\
\text { satisfaction }\end{array}$ & $\begin{array}{l}\text { Eid \& El- } \\
\text { Gohary } \\
(2015)\end{array}$ & 136 & $\begin{array}{l}\text { 1. Congregate the relation } \\
\text { between the theoretical } \\
\text { foundation of Islamic } \\
\text { tourism thoughts with } \\
\text { modern tourism paradigms. } \\
\text { 2. Investigate the moderating } \\
\text { effect of Islamic religiosity } \\
\text { on the relationship between } \\
\text { Muslim customer perceived } \\
\text { value (MCPV) and Muslim } \\
\text { customer satisfaction. }\end{array}$ & $\begin{array}{l}\text { 1. Quality, price, emotional value, social value, Islamic } \\
\text { physical attributes value, and Islamic non-physical } \\
\text { attributes value are the six dimensions of MCPV. } \\
\text { 2. MPCV have positive effect on the satisfaction of } \\
\text { Muslim consumer. These two variables are moderated } \\
\text { by Islamic religiosity. }\end{array}$ & $\begin{array}{l}\text { 1. Improve the understanding of } \\
\text { Islamic religiosity effect in other } \\
\text { business types. } \\
\text { 2. Assessed the other construct of } \\
\text { Islamic religiosity (aside from } \\
\text { beside Islamic belief and Islamic } \\
\text { practice). } \\
\text { 3. Assesses the other construct of } \\
\text { MCPV (aside the six construct } \\
\text { that already used in this study) }\end{array}$ \\
\hline 3. & $\begin{array}{l}\text { Halal tourism: } \\
\text { Concepts, } \\
\text { practices, } \\
\text { challenges and } \\
\text { future }\end{array}$ & $\begin{array}{l}\text { Battour \& } \\
\text { Ismail } \\
(2016)\end{array}$ & 129 & $\begin{array}{l}\text { 1. Investigate the halal } \\
\text { tourism concept along with } \\
\text { the components which } \\
\text { create the industry. } \\
\text { 2. Discusses the opportunities } \\
\text { and challenges of halal } \\
\text { tourism development and } \\
\text { marketing. }\end{array}$ & $\begin{array}{l}\text { 1. 'Halal tourism' is defined as "any tourism object or } \\
\text { action which is permissible according to Islamic } \\
\text { teaching to use or engage by Muslims in tourism } \\
\text { industry". } \\
\text { 2. Halal tourism is a competitive industry, and to be able } \\
\text { to compete in it, innovation is required. The innovation } \\
\text { can be in many forms, such as technology, or create } \\
\text { Muslim-friendly facilities and environment. }\end{array}$ & $\begin{array}{l}\text { 1. There is a need to develop a } \\
\text { Muslim friendly destination } \\
\text { construct, which criteria is } \\
\text { developed qualitative and } \\
\text { quantitively. } \\
\text { 2. There is a need to measure the } \\
\text { non-Muslim perceptions towards } \\
\text { halal tourism in Muslim and non- } \\
\text { Muslim destinations. }\end{array}$ \\
\hline
\end{tabular}

HALAL TOURISM RESEARCH EVALUTION: 10 YEARS AND GOING STRONG

(Sherly Artadita, Hisyam Hisyam) 
Jurnal Bisnis dan Manajemen, Volume 22, No. 2, September 2021, p. 96-126

\begin{tabular}{|c|c|c|c|c|c|c|}
\hline No. & $\begin{array}{l}\text { Document } \\
\text { Title }\end{array}$ & Author(s) & $\begin{array}{c}\text { Number of } \\
\text { Citation }\end{array}$ & Aim/Purpose & Findings & Future Research \\
\hline & & & & & $\begin{array}{l}\text { 3. The challenges of halal tourism is related to its terms, } \\
\text { the need of standardization system to ensure Halal } \\
\text { friendliness in its facilities, and the way to market Halal } \\
\text { tourism. }\end{array}$ & \\
\hline 4. & $\begin{array}{l}\text { The impact of } \\
\text { destination } \\
\text { attributes on } \\
\text { Muslim } \\
\text { tourist's choice }\end{array}$ & $\begin{array}{l}\text { Battour, } \\
\text { Ismail, \& } \\
\text { Battor } \\
\text { (2011) }\end{array}$ & 117 & $\begin{array}{l}\text { Explore Islamic attributes in } \\
\text { tourism destination that is } \\
\text { important for Muslim tourist. }\end{array}$ & $\begin{array}{l}\text { 1. Female respondents are more focus on privacy and } \\
\text { gender segregation on entertainment centers. } \\
\text { Meanwhile, male respondents are more focus on } \\
\text { worship facilities and issue related to Halal. } \\
\text { 2. The Islamic attributes are divided into two aspects: (a) } \\
\text { tangible aspects (e.g. prayer facilities and halal food), } \\
\text { and intangible aspects (e.g. Islamic entertainment, } \\
\text { general Islamic morality, and Islamic call (Azan) for } \\
\text { prayer). }\end{array}$ & $\begin{array}{l}\text { This study uses interview method in } \\
\text { collecting the data. Thus, future } \\
\text { research which evaluate the need of } \\
\text { Muslims traveler which conducted } \\
\text { empirically is needed. }\end{array}$ \\
\hline 5. & $\begin{array}{l}\text { Deciphering } \\
\text { 'Islamic } \\
\text { hospitality': } \\
\text { Developments, } \\
\text { challenges and } \\
\text { opportunities }\end{array}$ & $\begin{array}{l}\text { Stephenson } \\
\text { (2014) }\end{array}$ & 105 & $\begin{array}{l}\text { 1. Evaluate Islamic } \\
\text { hospitality principles and } \\
\text { practices. } \\
\text { 2. Outline the various ways in } \\
\text { which Islam converge with } \\
\text { 'hospitality' and } \\
\text { 'hospitality industry'. }\end{array}$ & $\begin{array}{l}\text { 1. Islamic hospitality has two elements: (a) intangible } \\
\text { elements (e.g. traditional interpretation and cultural } \\
\text { interpretation of Islamic hospitality); and (b) tangible } \\
\text { elements (e.g. the principles, practice, development, } \\
\text { and challenge of Islamic hotel sector, the trends and } \\
\text { development of the production and consumption of } \\
\text { halal food, the legitimation of halal product and } \\
\text { services, and the sector of Islamic festival and events). } \\
\text { 2. Halal hospitality can be developed and promoted not } \\
\text { only to attract Muslim market but also for non-Muslim } \\
\text { market, especially for those who concern about } \\
\text { product safety, social civility and lifestyle. } \\
\text { The development of halal airlines, Islamic village } \\
\text { tourism, and Islamic cruises as future development that } \\
\text { relate to Islamic hospitality. }\end{array}$ & 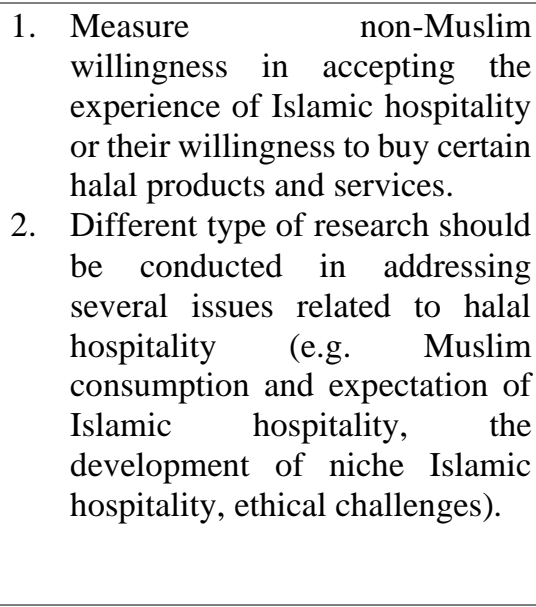 \\
\hline
\end{tabular}

Source: Processed data (2021). 
Jurnal Bisnis dan Manajemen, Volume 22, No. 2, September 2021, p. 96-126

This study also examines the top five publications with the most citation for further analysis in terms of aim of study, finding, and future research recommendation. Overall, all five publication is published from 2011 until 2016, which if according to data in Table 4, the number of publications is still fluctuated. The fluctuation can be happened because in that range of years, halal tourism research is still in introduction stage. As indicated from Table 5, the purpose and finding of these five publications mostly focused on defining the principle, definition, component, attributes, challenge, and opportunities in halal tourism or more specific sector of tourism industry that adopt Islamic law within its activity or operation.

Apparently, the research conducted by Jafari \& Scott (2014) entitled 'Muslim world and its tourism' dominating with 166 citations. The research is elaborate several event and issue that relate to Islam and tourism, such as the history of Islam expansion, the purpose of travelling for Muslim people and their potential problem when travelling to non-Muslim countries, also the challenge for Muslim countries in cater nonMuslim traveler. The complete evaluation of all 10 papers is presented in Table 5.
Surprisingly, those five documents are published in the top 10 journals with the most citations. Document number 1 is published in Annals of Tourism Research; documents number 2, and 5 are published in Tourism Management; documents number 3 is published in Tourism Management Perspective; and document number 4 is published in International Journal of Tourism Research. For the further examination, these four journal were compared based on the information on SCImago, which are shown in Table 6. The comparison imply that four journals have at least belongs to two different subject areas, meanwhile only Tourism Management Perspective journal falls on one subject area "Tourism, Leisure, and Hospitality Management". Probably because of its main focus, the researcher who conducted research related to tourism are more interested to published their publication in this journal. Moreover, if we looking back at Figure 5, this journal is on the first position as the most cited journal with 597 citations. Thus, there is a possibility that the authors, who published their research in this journal, has the high chance to be cited by the other people or researchers.

Table 6. The Comparison of Five Journals that Published the Research of Top 10 Most Cited Author

\begin{tabular}{|c|c|c|c|c|c|c|c|}
\hline $\begin{array}{c}\text { Journal } \\
\text { Name }\end{array}$ & Country & Publisher & $\begin{array}{c}\text { H- } \\
\text { index }\end{array}$ & Coverage & Subject Area & Category & $\begin{array}{c}\text { Quartiles in } \\
\mathbf{2 0 2 0}\end{array}$ \\
\hline $\begin{array}{l}\text { Annals of } \\
\text { Tourism } \\
\text { Research }\end{array}$ & $\begin{array}{l}\text { United } \\
\text { Kingdom }\end{array}$ & $\begin{array}{l}\text { Elsevier } \\
\text { Ltd. }\end{array}$ & 171 & $\begin{array}{l}1973- \\
2020\end{array}$ & $\begin{array}{c}\text { Business, } \\
\text { Management, and } \\
\text { Accounting }\end{array}$ & $\begin{array}{c}\text { Tourism, Leisure, and } \\
\text { Hospitality Management }\end{array}$ & Q1 \\
\hline
\end{tabular}


Jurnal Bisnis dan Manajemen, Volume 22, No. 2, September 2021, p. 96-126

\begin{tabular}{|c|c|c|c|c|c|c|c|}
\hline $\begin{array}{c}\text { Journal } \\
\text { Name }\end{array}$ & Country & Publisher & $\begin{array}{c}\text { H- } \\
\text { index }\end{array}$ & Coverage & Subject Area & Category & $\begin{array}{c}\text { Quartiles in } \\
2020\end{array}$ \\
\hline & & & & & Social Science & Development & Q1 \\
\hline \multirow{4}{*}{$\begin{array}{c}\text { Tourism } \\
\text { Management }\end{array}$} & \multirow{4}{*}{$\begin{array}{l}\text { United } \\
\text { Kingdom }\end{array}$} & \multirow{4}{*}{$\begin{array}{l}\text { Elsevier } \\
\text { Ltd. }\end{array}$} & \multirow{4}{*}{199} & \multirow{4}{*}{$\begin{array}{l}1982- \\
2021\end{array}$} & \multirow{2}{*}{$\begin{array}{c}\text { Business, } \\
\text { Management, and } \\
\text { Accounting }\end{array}$} & $\begin{array}{l}\text { Strategy and } \\
\text { Management }\end{array}$ & Q1 \\
\hline & & & & & & $\begin{array}{c}\text { Tourism, Leisure, and } \\
\text { Hospitality Management }\end{array}$ & Q1 \\
\hline & & & & & \multirow{2}{*}{ Social Science } & Development & Q1 \\
\hline & & & & & & Transportation & Q1 \\
\hline $\begin{array}{c}\text { Tourism } \\
\text { Management } \\
\text { Perspective }\end{array}$ & $\begin{array}{l}\text { United } \\
\text { States }\end{array}$ & $\begin{array}{l}\text { Elsevier } \\
\text { USA }\end{array}$ & 43 & $\begin{array}{l}2012- \\
2020\end{array}$ & $\begin{array}{c}\text { Business, } \\
\text { Management, and } \\
\text { Accounting }\end{array}$ & $\begin{array}{c}\text { Tourism, Leisure, and } \\
\text { Hospitality Management }\end{array}$ & Q1 \\
\hline \multirow{5}{*}{$\begin{array}{l}\text { International } \\
\text { Journal of } \\
\text { Tourism } \\
\text { Research }\end{array}$} & \multirow{5}{*}{$\begin{array}{l}\text { United } \\
\text { Kingdom }\end{array}$} & & \multirow{5}{*}{58} & \multirow{5}{*}{$\begin{array}{l}2008- \\
2020\end{array}$} & $\begin{array}{c}\text { Business, } \\
\text { Management, and } \\
\text { Accounting }\end{array}$ & $\begin{array}{c}\text { Tourism, Leisure, and } \\
\text { Hospitality Management }\end{array}$ & Q1 \\
\hline & & $\begin{array}{l}\text { John } \\
\text { Wiley }\end{array}$ & & & $\begin{array}{l}\text { Environmental } \\
\text { Science }\end{array}$ & $\begin{array}{c}\text { Nature and Landscape } \\
\text { Conservation }\end{array}$ & Q1 \\
\hline & & $\begin{array}{l}\text { and Sons } \\
\text { Ltd }\end{array}$ & & & Social Science & $\begin{array}{c}\text { Geography, Planning, } \\
\text { and Development }\end{array}$ & Q1 \\
\hline & & & & & & Transportation & Q1 \\
\hline & & & & & Social Science & $\begin{array}{c}\text { Geography, Planning, } \\
\text { and Development }\end{array}$ & Q1 \\
\hline
\end{tabular}

Source: SCImago (n.d.).

This study also evaluates the keyword that frequently used by authors. In total, 622 keywords were found in 230 documents, but this study only took the keyword that at least appears 5 times. This threshold is determined in order to find out the keywords that usually used in research related to halal tourism. After the filtration, only 28 keywords meet this threshold. The list of 28 keywords is shown in Table 7.

\section{Table 7. The List of 28 Keywords with Minimum Five Times Occurrence}

\begin{tabular}{|c|c|c|c|c|c|c|c|c|}
\hline No. & Keyword & Occurrences & No. & Keyword & Occurrences & No. & Keyword & Occurrences \\
\hline 1. & Halal Tourism & 73 & 11. & Religiosity & 9 & 21. & Muslims & 6 \\
\hline 2. & Islamic Tourism & 42 & 12. & $\begin{array}{c}\text { Tourist } \\
\text { Satisfaction }\end{array}$ & 9 & 22. & Service Quality & 6 \\
\hline 3. & Tourism & 21 & 13. & Indonesia & 8 & 23. & $\begin{array}{l}\text { Destination } \\
\text { Marketing }\end{array}$ & 5 \\
\hline 4. & Malaysia & 20 & 14. & Islamic Hospitality & 8 & 24. & Halal Market & 5 \\
\hline
\end{tabular}


Jurnal Bisnis dan Manajemen, Volume 22, No. 2, September 2021, p. 96-126

\begin{tabular}{|c|c|c|c|c|c|c|c|c|}
\hline No. & Keyword & Occurrences & No. & Keyword & Occurrences & No. & Keyword & Occurrences \\
\hline 5. & Islam & 19 & 15. & Halal Hospitality & 7 & 25. & $\begin{array}{c}\text { Islamic } \\
\text { Destination }\end{array}$ & 5 \\
\hline 6. & Halal & 14 & 16. & Religion & 7 & 26. & $\begin{array}{c}\text { Islamic } \\
\text { Destinations }\end{array}$ & 5 \\
\hline 7. & Muslim Tourists & 13 & 17. & Religious Tourism & 7 & 27 & Loyalty & 5 \\
\hline 8. & Satisfaction & 13 & 18. & $\begin{array}{l}\text { Customer } \\
\text { Satisfaction }\end{array}$ & 6 & 28. & Pilgrimage & 5 \\
\hline 9. & $\begin{array}{c}\text { Destination } \\
\text { Image }\end{array}$ & 10 & 19. & Halal Certification & 6 & & & \\
\hline 10. & $\begin{array}{c}\text { Islamic } \\
\text { Attributes }\end{array}$ & 9 & 20. & Muslim Travelers & 6 & & & \\
\hline
\end{tabular}

Source: Processed data (2021).

Usually, we rarely found a publication with only one keyword, because mostly this keyword paired with other keywords to represent or give a general idea of certain publication. According to Merriam-Webster Dictionary, key word is a noun word with definition "a significant word from a title of document used especially as an index to content" (Merriam-Webster, n.d.).

In addition, this study evaluated the link or connectedness between all 28 keywords by making a map based on Bibliographic data (Figure 7). Two distinctive features that can be seen in the map are its circle size and its colour. The circle size implies the occurrence of each keyword (i.e. bigger circle indicates the keyword has higher occurrence compared with the occurrence in smaller circle). Figure 7 pinpoint that 'Halal Tourism' has the largest circle size, meaning that this keyword has highest occurrence, and often used by the authors. This thing is in line with the data in Table 7 which show that 'halal tourism' keyword' is occur 73 times in 230 documents. Another example, 'Islamic Tourism', which occur 42 times, has the second largest circle in Figure 7. Followed by, 'Tourism', 'Malaysia', and 'Islam', in the third, fourth, and fifth circle size, respectively.

For color, it represents the cluster of keywords. In this study, the 28 keywords are grouping into three clusters:

- Cluster 1 (11 items, red colour): destination image, destination marketing, Islamic attributes, Islamic destination, Islamic destinations, Islamic tourism, loyalty, Muslim tourist, satisfaction, service quality, tourist satisfaction.

- Cluster 2 (9 items, green colour): halal, Indonesia, Islam, Malaysia, Muslims, pilgrimage, religion, religious tourism, tourism.

- Cluster 3 (8 items, blue colour): customer satisfaction, halal certification, halal hospitality, halal market, halal tourism, Islamic hospitality, Muslim travelers, religiosity. 
Jurnal Bisnis dan Manajemen, Volume 22, No. 2, September 2021, p. 96-126

\& VOSviewer

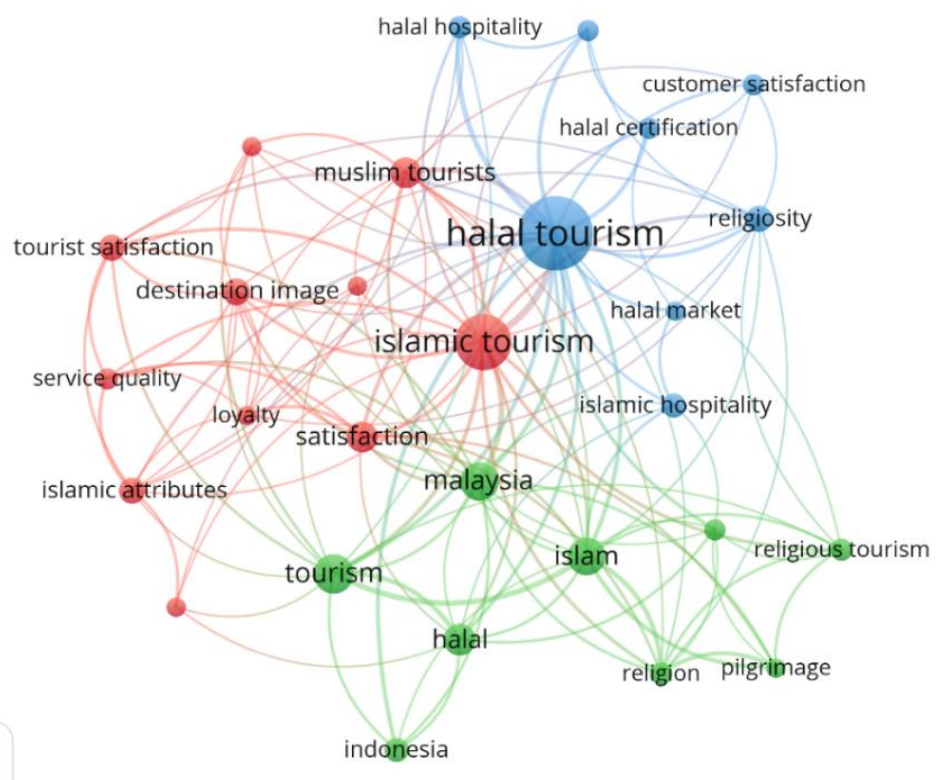

Figure 7. Map based on Bibliographic Data - Network Visualization Source: Processed data (2021).
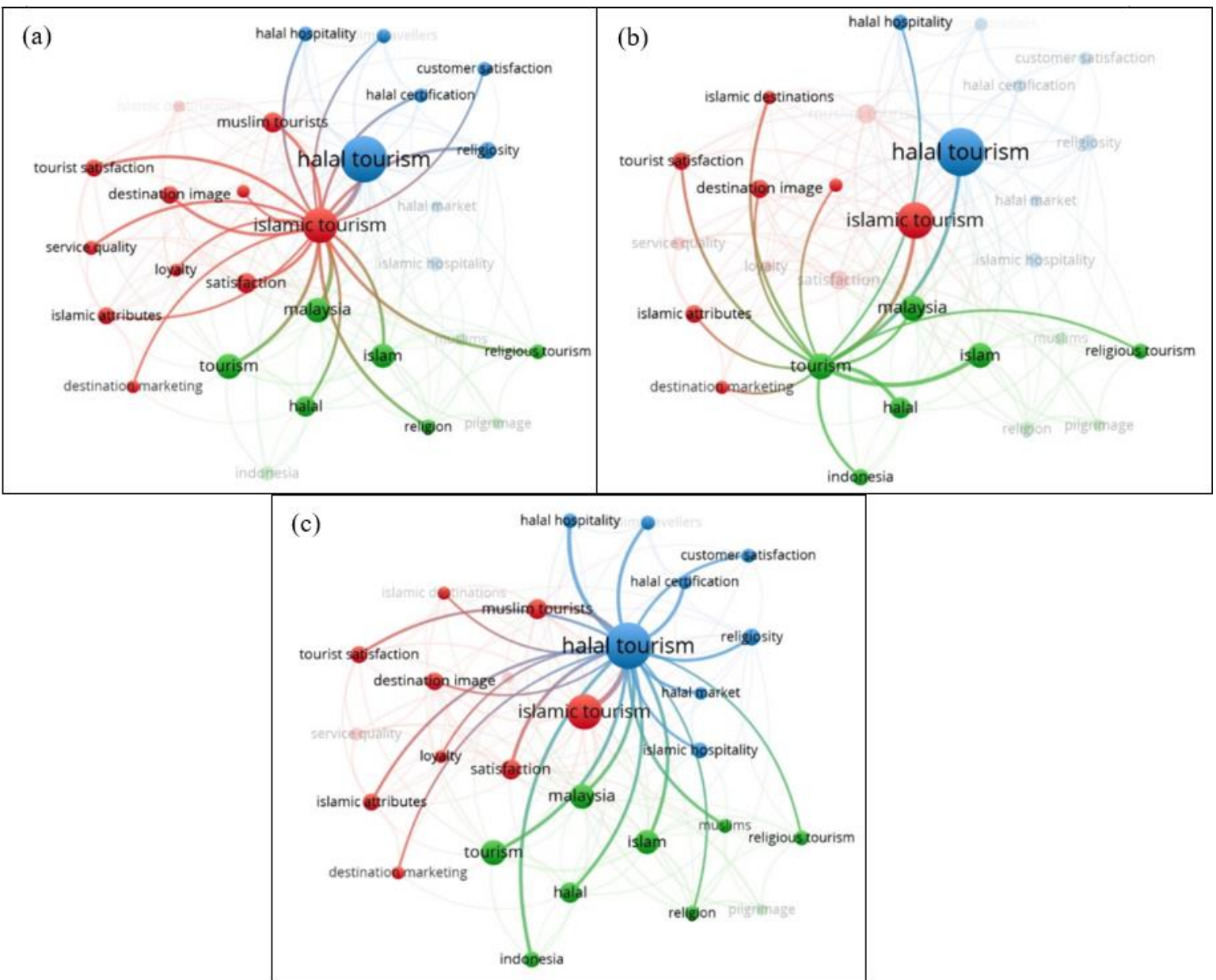

Figure 8. (a) Cluster 1 - Islamic Tourism; (b) Cluster 2 - Tourism; and (c) Cluster 3 - Halal Tourism Source: Processed data (2021). 
Jurnal Bisnis dan Manajemen, Volume 22, No. 2, September 2021, p. 96-126

Table 8. Cluster 1's Keyword and its Connectivity with All 28 Keywords

\begin{tabular}{|c|c|c|c|c|c|c|c|c|c|c|c|c|}
\hline \multirow{3}{*}{ Cluster } & \multirow[b]{3}{*}{ Keyword } & \multirow{2}{*}{\multicolumn{11}{|c|}{ Cluster 1}} \\
\hline & & & & & & & & & & & & \\
\hline & & $\begin{array}{c}\text { Destination } \\
\text { Image }\end{array}$ & $\begin{array}{l}\text { Destination } \\
\text { marketing }\end{array}$ & $\begin{array}{c}\text { Islamic } \\
\text { attributes }\end{array}$ & $\begin{array}{c}\text { Islamic } \\
\text { destination }\end{array}$ & $\begin{array}{c}\text { Islamic } \\
\text { destinations }\end{array}$ & $\begin{array}{c}\text { Islamic } \\
\text { tourism }\end{array}$ & Loyalty & $\begin{array}{c}\text { Muslim } \\
\text { tourist }\end{array}$ & Satisfaction & $\begin{array}{l}\text { Service } \\
\text { quality }\end{array}$ & $\begin{array}{c}\text { Tourist } \\
\text { Satisfaction }\end{array}$ \\
\hline \multirow{11}{*}{$\begin{array}{c}\text { Cluster } \\
1\end{array}$} & $\begin{array}{c}\text { Destination } \\
\text { image }\end{array}$ & & & $\sqrt{ }$ & $\sqrt{ }$ & $\sqrt{ }$ & $\sqrt{ }$ & $\sqrt{ }$ & & $\sqrt{ }$ & $\sqrt{ }$ & $\sqrt{ }$ \\
\hline & $\begin{array}{l}\text { Destination } \\
\text { marketing }\end{array}$ & & & $\sqrt{ }$ & & & $\sqrt{ }$ & & & & & \\
\hline & $\begin{array}{c}\text { Islamic } \\
\text { attributes }\end{array}$ & $\sqrt{ }$ & $\sqrt{ }$ & & & & $\sqrt{ }$ & $\sqrt{ }$ & $\sqrt{ }$ & & $\sqrt{ }$ & $\sqrt{ }$ \\
\hline & $\begin{array}{c}\text { Islamic } \\
\text { destination }\end{array}$ & $\sqrt{ }$ & & & & & $\sqrt{ }$ & & $\sqrt{ }$ & & & \\
\hline & $\begin{array}{c}\text { Islamic } \\
\text { destinations }\end{array}$ & $\sqrt{ }$ & & & & & & & $\sqrt{ }$ & & & $\sqrt{ }$ \\
\hline & $\begin{array}{l}\text { Islamic } \\
\text { tourism }\end{array}$ & $\sqrt{ }$ & $\sqrt{ }$ & $\sqrt{ }$ & $\sqrt{ }$ & & 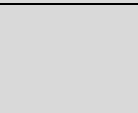 & $\sqrt{ }$ & $\sqrt{ }$ & $\sqrt{ }$ & $\sqrt{ }$ & $\sqrt{ }$ \\
\hline & Loyalty & $\sqrt{ }$ & & $\sqrt{ }$ & & & $\sqrt{ }$ & & $\sqrt{ }$ & $\sqrt{ }$ & $\sqrt{ }$ & \\
\hline & $\begin{array}{c}\text { Muslim } \\
\text { tourist }\end{array}$ & - & & $\sqrt{ }$ & $\sqrt{ }$ & $\sqrt{ }$ & $\sqrt{ }$ & $\sqrt{ }$ & & $\sqrt{ }$ & & \\
\hline & Satisfaction & $\sqrt{ }$ & & & & & $\sqrt{ }$ & $\sqrt{ }$ & $\sqrt{ }$ & & $\sqrt{ }$ & \\
\hline & $\begin{array}{l}\text { Service } \\
\text { quality }\end{array}$ & $\sqrt{ }$ & & $\sqrt{ }$ & & & $\sqrt{ }$ & $\sqrt{ }$ & & $\sqrt{ }$ & & $\sqrt{ }$ \\
\hline & $\begin{array}{c}\text { Tourist } \\
\text { Satisfaction }\end{array}$ & $\sqrt{ }$ & & $\sqrt{ }$ & & $\sqrt{ }$ & $\sqrt{ }$ & & & & $\sqrt{ }$ & \\
\hline & Halal & & $\sqrt{ }$ & & & & $\sqrt{ }$ & & & $\sqrt{ }$ & & \\
\hline
\end{tabular}

HALAL TOURISM RESEARCH EVALUTION: 10 YEARS AND GOING STRONG

(Sherly Artadita, Hisyam Hisyam) 
Jurnal Bisnis dan Manajemen, Volume 22, No. 2, September 2021, p. 96-126

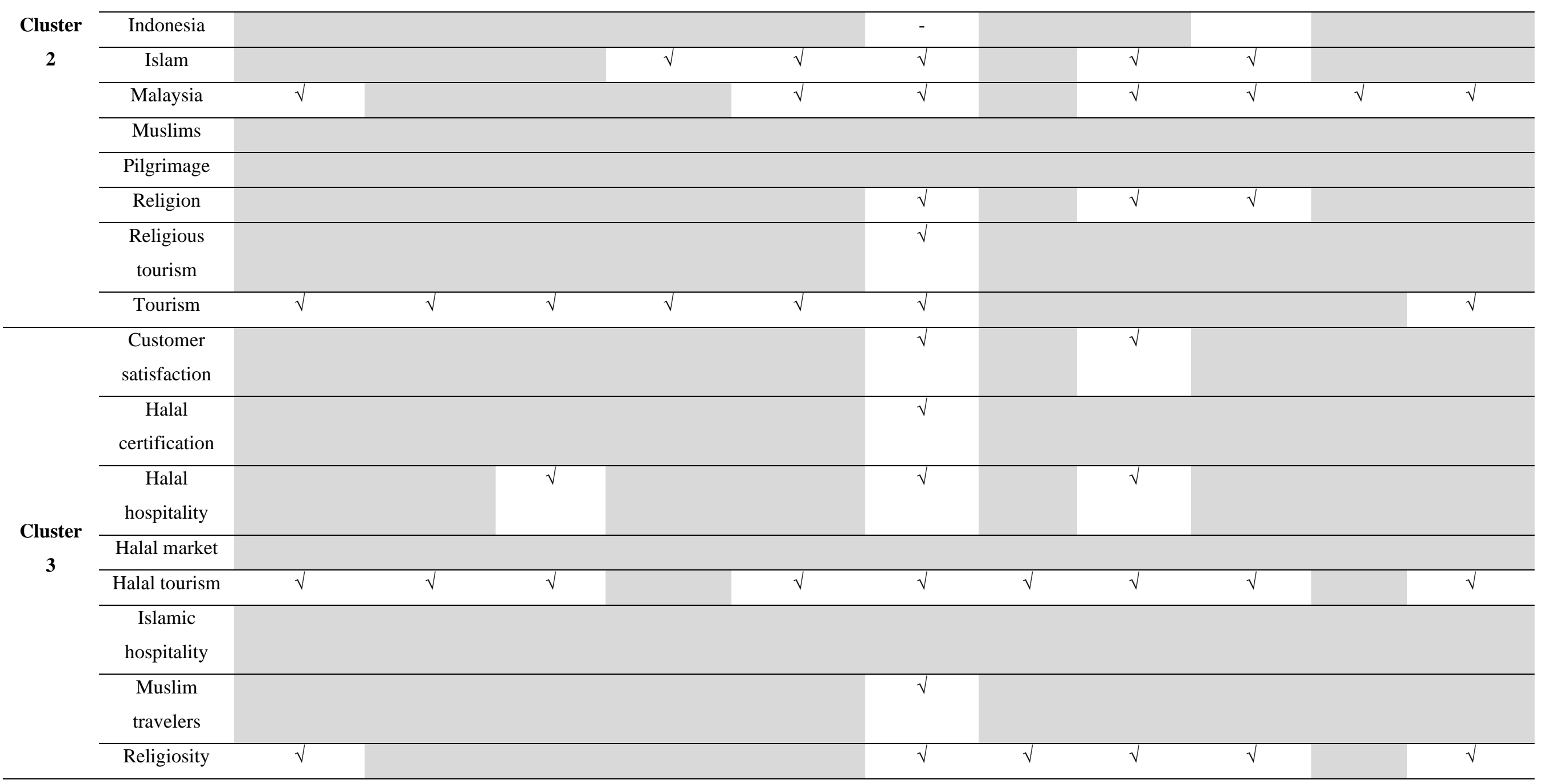

Source: Processed data (2021). 
Jurnal Bisnis dan Manajemen, Volume 22, No. 2, September 2021, p. 96-126

Table 9. Cluster 2's Keyword and its Connectivity with All 28 Keywords

\begin{tabular}{|c|c|c|c|c|c|c|c|c|c|c|}
\hline \multirow{2}{*}{ Cluster } & \multirow{2}{*}{ Keyword } & \multicolumn{9}{|c|}{ Cluster 2} \\
\hline & & Halal & Indonesia & Islam & Malaysia & Muslims & Pilgrimage & Religion & $\begin{array}{l}\text { Religious } \\
\text { Tourism }\end{array}$ & Tourism \\
\hline \multirow{12}{*}{$\begin{array}{c}\text { Cluster } \\
1\end{array}$} & $\begin{array}{c}\text { Destination } \\
\text { image }\end{array}$ & & & & $\sqrt{ }$ & & & & & $\sqrt{ }$ \\
\hline & $\begin{array}{c}\text { Destination } \\
\text { marketing }\end{array}$ & $\sqrt{ }$ & & & & & & & & $\sqrt{ }$ \\
\hline & $\begin{array}{c}\text { Islamic } \\
\text { attributes }\end{array}$ & & & & & & & & & $\sqrt{ }$ \\
\hline & $\begin{array}{c}\text { Islamic } \\
\text { destination }\end{array}$ & & & $\sqrt{ }$ & & & & & & $\sqrt{ }$ \\
\hline & $\begin{array}{c}\text { Islamic } \\
\text { destinations }\end{array}$ & & & $\sqrt{ }$ & $\sqrt{ }$ & & & & & $\sqrt{ }$ \\
\hline & $\begin{array}{l}\text { Islamic } \\
\text { tourism }\end{array}$ & $\sqrt{ }$ & & $\sqrt{ }$ & $\sqrt{ }$ & & & $\sqrt{ }$ & $\sqrt{ }$ & \\
\hline & Loyalty & & & & & & & & & \\
\hline & $\begin{array}{l}\text { Muslim } \\
\text { tourist }\end{array}$ & & & $\sqrt{ }$ & $\sqrt{ }$ & & & $\sqrt{ }$ & & \\
\hline & Satisfaction & $\sqrt{ }$ & & $\sqrt{ }$ & $\sqrt{ }$ & & $\sqrt{ }$ & $\sqrt{ }$ & & \\
\hline & $\begin{array}{l}\text { Service } \\
\text { quality }\end{array}$ & & & & $\sqrt{ }$ & & & & & \\
\hline & $\begin{array}{c}\text { Tourist } \\
\text { Satisfaction }\end{array}$ & & & & $\sqrt{ }$ & & & & & $\sqrt{ }$ \\
\hline & Halal & & $\sqrt{ }$ & $\sqrt{ }$ & $\sqrt{ }$ & $\sqrt{ }$ & & & & $\sqrt{ }$ \\
\hline
\end{tabular}

HALAL TOURISM RESEARCH EVALUTION: 10 YEARS AND GOING STRONG

(Sherly Artadita, Hisyam Hisyam) 
Jurnal Bisnis dan Manajemen, Volume 22, No. 2, September 2021, p. 96-126

\begin{tabular}{|c|c|c|c|c|c|c|c|c|c|c|}
\hline \multirow{8}{*}{$\begin{array}{c}\text { Cluster } \\
2\end{array}$} & Indonesia & $\sqrt{ }$ & & $\sqrt{ }$ & $\sqrt{ }$ & & & & & $\sqrt{ }$ \\
\hline & Islam & $\sqrt{ }$ & $\sqrt{ }$ & & $\sqrt{ }$ & $\sqrt{ }$ & $\sqrt{ }$ & $\sqrt{ }$ & $\sqrt{ }$ & $\sqrt{ }$ \\
\hline & Malaysia & $\sqrt{ }$ & $\sqrt{ }$ & $\sqrt{ }$ & . & $\sqrt{ }$ & $\sqrt{ }$ & $\sqrt{ }$ & & $\sqrt{ }$ \\
\hline & Muslims & $\sqrt{ }$ & & $\sqrt{ }$ & $\sqrt{ }$ & & $\sqrt{ }$ & $\sqrt{ }$ & $\sqrt{ }$ & \\
\hline & Pilgrimage & & & $\sqrt{ }$ & $\sqrt{ }$ & $\sqrt{ }$ & & $\sqrt{ }$ & $\sqrt{ }$ & \\
\hline & Religion & & & $\sqrt{ }$ & $\sqrt{ }$ & $\sqrt{ }$ & $\sqrt{ }$ & & $\sqrt{ }$ & \\
\hline & $\begin{array}{l}\text { Religious } \\
\text { tourism }\end{array}$ & & & $\sqrt{ }$ & & $\sqrt{ }$ & $\sqrt{ }$ & $\sqrt{ }$ & & $\sqrt{ }$ \\
\hline & Tourism & $\sqrt{ }$ & $\sqrt{ }$ & $\sqrt{ }$ & $\sqrt{ }$ & & & & $\sqrt{ }$ & \\
\hline \multirow{8}{*}{$\begin{array}{c}\text { Cluster } \\
\mathbf{3}\end{array}$} & $\begin{array}{l}\text { Customer } \\
\text { satisfaction }\end{array}$ & & & & & & & & & \\
\hline & $\begin{array}{c}\text { Halal } \\
\text { certification }\end{array}$ & & & & & & & & & \\
\hline & $\begin{array}{c}\text { Halal } \\
\text { hospitality }\end{array}$ & & & & & & & & & $\sqrt{ }$ \\
\hline & Halal market & & & & & & & & & \\
\hline & Halal tourism & $\sqrt{ }$ & $\sqrt{ }$ & $\sqrt{ }$ & $\sqrt{ }$ & $\sqrt{ }$ & & $\sqrt{ }$ & $\sqrt{ }$ & $\sqrt{ }$ \\
\hline & $\begin{array}{c}\text { Islamic } \\
\text { hospitality }\end{array}$ & $\sqrt{ }$ & & $\sqrt{ }$ & $\sqrt{ }$ & $\sqrt{ }$ & & & & \\
\hline & $\begin{array}{l}\text { Muslim } \\
\text { travelers }\end{array}$ & & & & & & & & & \\
\hline & Religiosity & & & $\sqrt{ }$ & & & & $\sqrt{ }$ & $\sqrt{ }$ & \\
\hline
\end{tabular}

Source: Processed data (2021). 
Jurnal Bisnis dan Manajemen, Volume 22, No. 2, September 2021, p. 96-126

Table 10. Cluster 3's Keyword and its Connectivity with All 28 Keywords

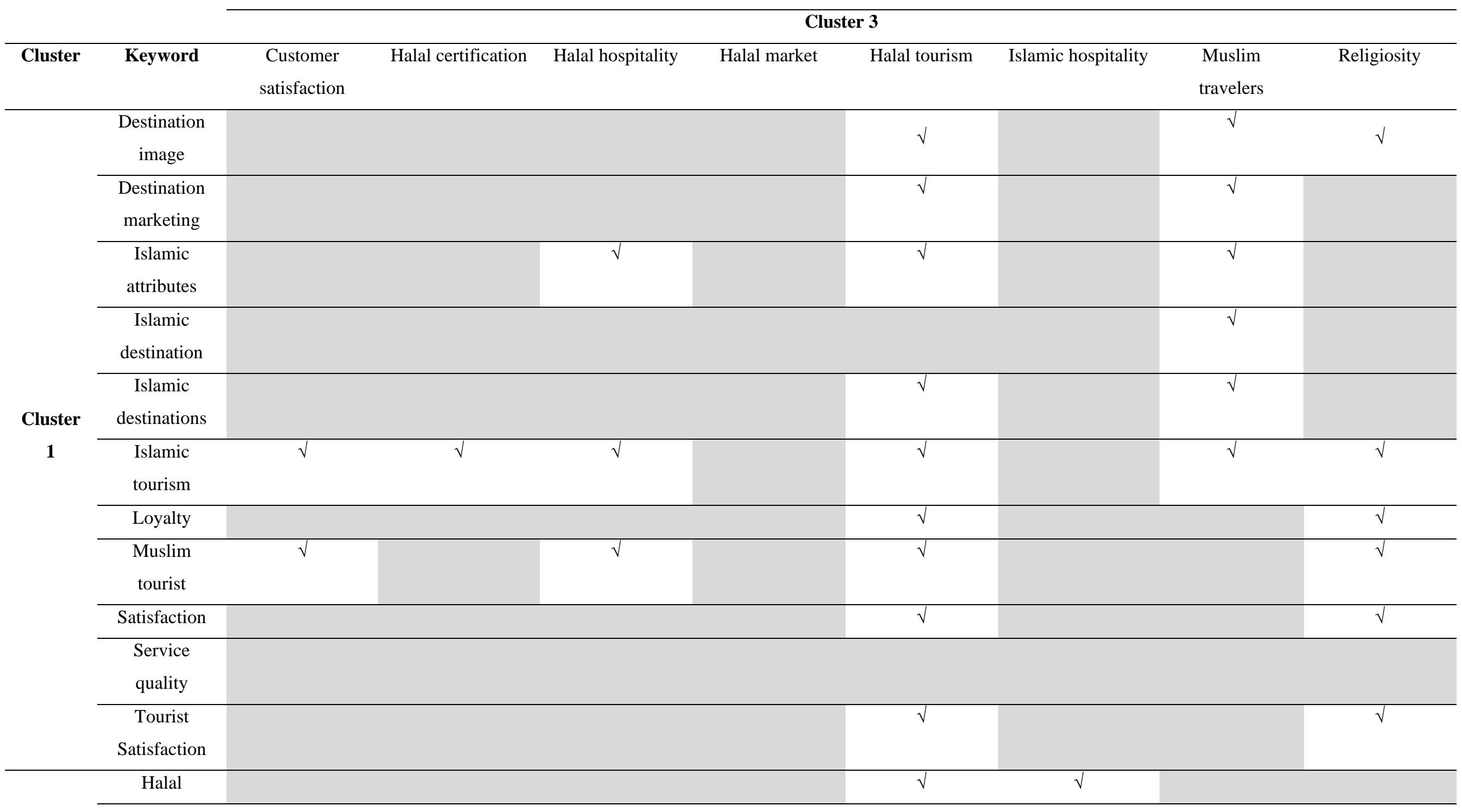

HALAL TOURISM RESEARCH EVALUTION: 10 YEARS AND GOING STRONG

(Sherly Artadita, Hisyam Hisyam) 
Jurnal Bisnis dan Manajemen, Volume 22, No. 2, September 2021, p. 96-126

\begin{tabular}{|c|c|c|c|c|c|c|c|c|c|}
\hline \multirow{8}{*}{$\begin{array}{c}\text { Cluster } \\
2\end{array}$} & Indonesia & & & & & $\sqrt{ }$ & & & \\
\hline & Islam & & & & & $\sqrt{ }$ & $\sqrt{ }$ & & $\sqrt{ }$ \\
\hline & Malaysia & & & & & $\sqrt{ }$ & $\sqrt{ }$ & & \\
\hline & Muslims & & & & & $\sqrt{ }$ & $\sqrt{ }$ & & \\
\hline & Pilgrimage & & & & & & & & \\
\hline & Religion & & & & & $\sqrt{ }$ & & & $\sqrt{ }$ \\
\hline & $\begin{array}{l}\text { Religious } \\
\text { tourism }\end{array}$ & & & & & $\sqrt{ }$ & & & $\sqrt{ }$ \\
\hline & Tourism & & & $\sqrt{ }$ & & $\sqrt{ }$ & & & \\
\hline \multirow{8}{*}{$\begin{array}{c}\text { Cluster } \\
\mathbf{3}\end{array}$} & $\begin{array}{l}\text { Customer } \\
\text { satisfaction }\end{array}$ & & $\sqrt{ }$ & & & $\sqrt{ }$ & & & $\sqrt{ }$ \\
\hline & $\begin{array}{c}\text { Halal } \\
\text { certification }\end{array}$ & $\sqrt{ }$ & & & $\sqrt{ }$ & $\sqrt{ }$ & & $\sqrt{ }$ & \\
\hline & $\begin{array}{c}\text { Halal } \\
\text { hospitality }\end{array}$ & & & & $\sqrt{ }$ & $\sqrt{ }$ & & $\sqrt{ }$ & \\
\hline & Halal market & & $\sqrt{ }$ & & $\sqrt{ }$ & $\sqrt{ }$ & $\sqrt{ }$ & & \\
\hline & Halal tourism & $\sqrt{ }$ & $\sqrt{ }$ & $\sqrt{ }$ & $\sqrt{ }$ & & $\sqrt{ }$ & $\sqrt{ }$ & $\sqrt{ }$ \\
\hline & $\begin{array}{c}\text { Islamic } \\
\text { hospitality }\end{array}$ & & & & $\sqrt{ }$ & $\sqrt{ }$ & & & \\
\hline & $\begin{array}{l}\text { Muslim } \\
\text { travelers }\end{array}$ & & $\sqrt{ }$ & $\sqrt{ }$ & $\sqrt{ }$ & $\sqrt{ }$ & & & $\sqrt{ }$ \\
\hline & Religiosity & $\sqrt{ }$ & & & $\sqrt{ }$ & $\sqrt{ }$ & & $\sqrt{ }$ & \\
\hline
\end{tabular}

Source: Processed data (2021). 
The link or line that connect one circle with another circle imply that the keyword usually uses concurrently in certain document with the other keywords that connected. Meanwhile, when one keyword does not have any connected line to another keyword, it means they do not use concurrently in a document. To make it easier to see, the link or connected line between the keywords are presented in checklist form as shown in Table 8 (Cluster 1), Table 9 (Cluster 2), and Table 10 (Cluster 3). Meanwhile, for the keyword that do not have any connectedness with another keyword, is presented by grey cell.

Cluster 1 consists of 11 keywords, with 'Islamic tourism' as the prime keyword (Figure 8a). This keyword is connected with the other 21 keywords from all three clusters:

- Cluster 1 (9 items): destination image, destination marketing, Islamic attributes, Islamic destination, loyalty, Muslim tourist, satisfaction, service quality, tourist satisfaction.

- Cluster 2 (6 items): halal, Islam, Malaysia, religion, religious tourism, tourism.

- Cluster 3 (6 items): customer satisfaction, halal certification, halal hospitality, halal tourism, Muslim travelers, religiosity.

Cluster 2 consists of 9 keywords, with 'tourism' as the prime keyword (Figure 8b). This keyword is connected with the other 14 keywords from all three clusters:

- Cluster 1 (7 items): destination image, destination marketing, Islamic attributes,
Islamic destination, Islamic destinations, Islamic tourism, tourist satisfaction.

- Cluster 2 (5 items): halal, Indonesia, Islam, Malaysia, religious tourism.

- Cluster 3 (2 items): halal hospitality, halal tourism.

It means that around a half of all identified keyword has not used concurrently with 'tourism'. It might be because the researchers prefer to use those keywords jointly with the other two prime keyword from Cluster 1 (i.e., Islamic tourism) and Cluster 2 (i.e., halal tourism).

Cluster 3 consists of eight keywords, with 'halal tourism' as the prime keyword (Figure 8c). This keyword is connected with almost all 28 other keywords, except Islamic destination, service quality, and pilgrimage. Thus, it is assumed that from 2011 until 2020 there is no publication in which these three keywords are used with 'halal tourism' in same publication. This situation actually a chance for researcher to explore and combine these four keywords. But actually, among those three keywords, 'service quality' is the one which has high potential to be paired with 'halal tourism' for the future research.

This suggestion is based on two reasoning: (1) The keyword 'Islamic destination' is probably expressed in plural form 'Islamic destinations' when it connected with 'halal tourism', and (2) The keyword 'pilgrimage' is more related to 'religious tourism' as stated in Table 7. This is due to the activity of halal tourism that more emphasizing on the creation of tourism destination that Muslim- 
Jurnal Bisnis dan Manajemen, Volume 22, No. 2, September 2021, p. 96-126

friendly, rather than focus on religious activity. On the other hand, 'pilgrimage' is a pilgrim who visit a sacred or holy place for religious motive. Hence, the pilgrimage will choose 'religious tourism' which more suitable for their purpose.

Other than that, there is an issue that need to be addressed regarding the usage of 'Halal tourism' and 'Islamic tourism'. Often, these two keywords are used interchangeably by the researchers. Which actually, these two terms are slightly different. 'Halal' is defined as something that permissible by Shariah law or Islamic teaching, meanwhile 'Islamic' is applied only to something that relates directly to the faith and must be supported by intention to find God pleasure (Battour \& Ismail, 2016). So, it can be said that halal tourism is more focusing on creating tourism place that Muslimfriendly, while Islamic tourism is designed for those who has intention to worship the God or to recall the history of Islam.

In addition to expound the result from the analysis of keyword's network, Figure 8 illustrate the overlay of each keyword which indicates the development of keywords over the years. By default, the blue color represent the scores less than or equal to minimum score, green color are the intermediate scores, and yellow color are for the scores greater than or equal to the maximum score (van Eck \& Waltman, 2013). In this study, the score was set based on the average years of publication with minimum score '2016' and the maximum score '2019'.

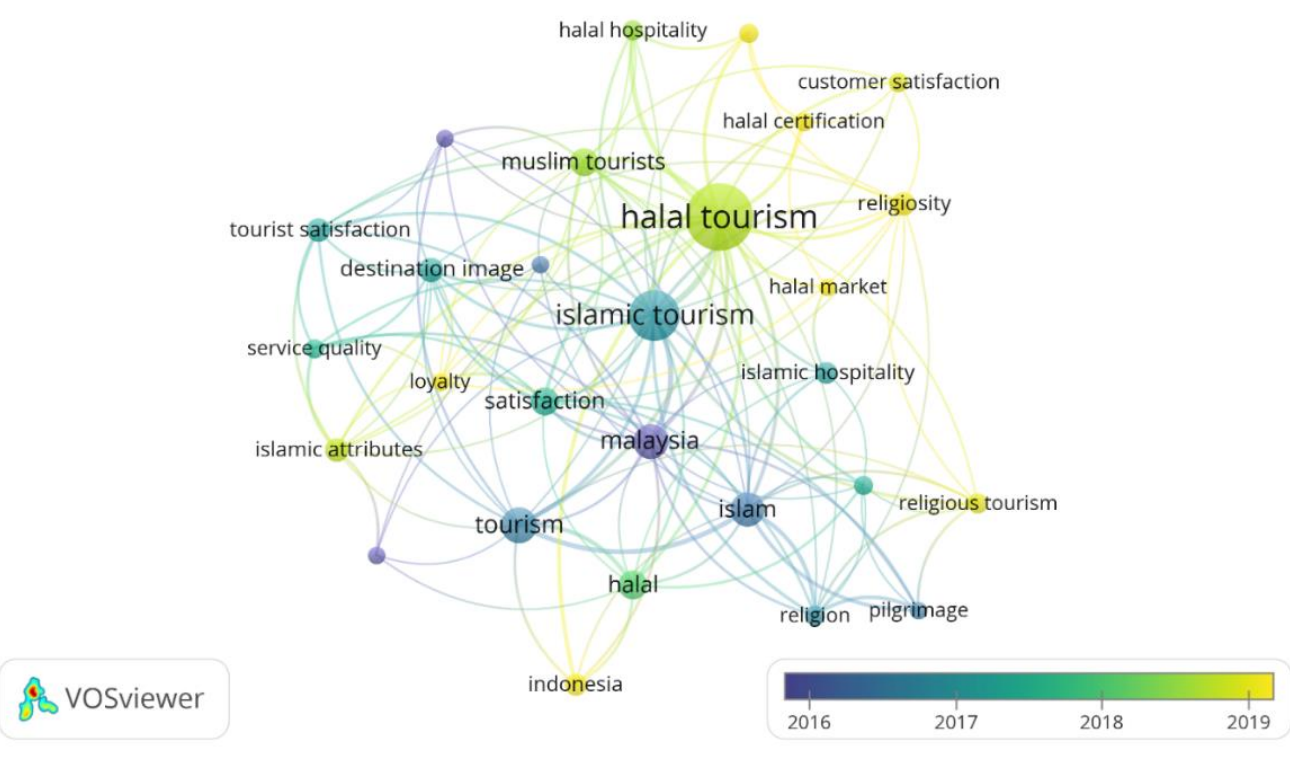

Figure 9. Map based on Bibliographic Data - Overlay Visualization Source: Processed data (2021).

Figure 8 imply that several keywords such as 'customer satisfaction', 'Muslim travelers', 'halal certification', 'religiosity', 'halal market', 'loyalty', 'religious tourism', and 'Indonesia' are the popular keyword that emerge since 2019.
Which is, if we look back in 2016, the popular keywords are 'Muslim tourist', 'destination marketing', and 'Malaysia'. Meanwhile for the rest keywords are mostly used between 2016 until 2019. But, it does not mean that the keyword 
Jurnal Bisnis dan Manajemen, Volume 22, No. 2, September 2021, p. 96-126

that used before 2019, not appealing to be evaluated in today's research. For example, 'service quality' is only connected to seven keywords (as shown in Table 8) and more importantly has not used concurrently by the authors with 'halal tourism' as document's keyword.

The situation above is unfortunate because service is an important aspect of halal tourism, that own $40 \%$ weight of total score in the evaluation of Global Muslim Travel Index. Thus, by focusing more on the service area, especially its quality on providing proper halal food/restaurant, prayer facilities, hotel, airports, and attraction, which suitable with the need of Muslim tourist. Papastathopoulos et al. (2020) unveil three types of Muslim tourist with different preferences of services that should be provided in halal tourism. The first group is "utilitarian Muslim guest" that asses services based on the availability, approachability, and convenience of use. The second group is "independent Muslim guest" that assess services based on its capability in digital communication. The last is "leisure Muslim guest" group that assess services based on the peace that they will get from destination environment. Seeing those preferences, indicate the diversity of people preferences in evaluating the quality of services in halal tourism, which should be addressed not only by the academics, but also by the government and tourism providers.

\section{CONCLUSION}

The analysis based on Bibliometric data reveal that most of research related to halal tourism from 2011-2020 are published in the form of articles. The publications are fluctuated in 2011 until 2014 , and it start to grow steadily after the fall in 2015, with the peak 73 publications in 2020. Malaysia is the leading country in halal tourism related publication, followed by Indonesia and the United Kingdom, in second and third position, respectively. But, for the most citation publication based on country, Indonesia beaten by Egypt (i.e., Malaysia and UK still in number 1 and 3).

Overall, since 2011 until 2020 authors published their articles in 110 Scopus indexed journal. Among them, Tourism Management Perspective is the most cited journal with 597 citations. This journal is a journal that focus on travel and tourism planning and management. Furthermore, among 230 documents in the data set, the research conducted by Jafari J. \& Scott N. (2014), which focus on the combination of Islam and tourism, got 166 citations in 2011-2020.

The top three most used keyword among the authors are 'halal tourism', 'Islamic tourism', and 'tourism', with occurrence 73 time, 42 times, and 21 times, respectively. These three keywords become the main keywords of three different clusters (i.e., Cluster 1, Cluster 2, and Cluster 3) on the map of bibliometric data. This map also reveals the connected line among all 28 keywords. Among them, 'halal tourism' is the keyword with the most connected line to the other keywords (25 
Jurnal Bisnis dan Manajemen, Volume 22, No. 2, September 2021, p. 96-126

keywords), followed by 'Islamic tourism' and 'tourism' which connected with the other 21 keywords and 14 keywords, respectively.

The analysis also giving implication for academics. The result pointed that the involvement of 'service quality' in halal tourism research is still scarce. Then, the future research should address this opportunity. Additionally, in the midst of Covid-19 pandemic which hit the world since 2020, tourism sector become one of the sectors that get the biggest impact due to the worldwide travel restriction as one of the causes. Thus, by focusing on creating a great service quality strategy in halal tourism, hopefully could attract both Muslim and non-Muslim tourist, and become a solution for tourism sector recovery.

Along with this notion, the implication for practice also existed. To provide halal tourism with great service quality, the involvement of government and tourism service providers are taken into consideration. The government should create a policy regarding the provision of the 'must have' facilities in halal tourism destination (e.g., halal hotel, halal restaurant, proper prayer facilities), which supported by the rules how to operate those facilities (i.e., what requirements that must be fulfilled). This policy is created in order to make Muslim tourist feeling in ease to live based on Sharia (e.g., conduct a prayer, eat halal food and beverages, seeing allowable entertainment, etc.). In the same time, the service providers or the business owner of halal tourism provide these requirements and necessity by lift up their service quality to match tourist's requirements and government's policy.

Additionally, this study is not free from limitations. First, the data set were obtained only from 'Scopus' database. Thus, the publication that were not included in this study could be analyzed in another research. Second, this study was examined in general level. So, similar study which also adopt bibliometric data analysis could be conducted, either by limiting the study in certain journal name or certain regional level. Third, the selection of document type are not restricted to specific type. Thus, similar research in the future could be conducted by focusing on one type of document (e.g., journal articles only) to get deeper understanding of halal tourism trend, that mostly discussed or evaluated in that type of document.

\section{REFERENCES}

Asnawi, N., Sukoco, B. M., \& Fanani, M. A. (2018). Halal products consumption in international chain restaurants among global Moslem consumers. International Journal of Emerging Markets, 13(5), 1273-1290. https://doi.org/10.1108/IJoEM-112017-0495

Battour, M., \& Ismail, M. N. (2016). Halal tourism: Concepts, practises, challenges and future. Tourism Management Perspectives. https://doi.org/10.1016/j.tmp.2015.12.008

Battour, M., Ismail, M. N., \& Battor, M. (2011). The impact of destination attributes on Muslim tourist's choice. International Journal of Tourism Research, 13(6), 527-540. https://doi.org/10.1002/jtr.824

Boğan, E., \& Sarışık, M. (2019). Halal tourism: conceptual and practical challenges. Journal of Islamic Marketing. https://doi.org/10.1108/JIMA06-2017-0066

Chicksand, D., Watson, G., Walker, H., Radnor, Z., \& Johnston, R. (2012). Theoretical perspectives in purchasing and supply chain management: An analysis of the literature. Supply Chain Management, $\quad$ 17(4), 454-472. 
Jurnal Bisnis dan Manajemen, Volume 22, No. 2, September 2021, p. 96-126

https://doi.org/10.1108/13598541211246611

COMCEC Coordination Office. (2018). Comcec Tourism Outlook 2018. (August), 1-56.

DinarStandard. (2019). State of the Global Islamic Economy Report 2019/20. 1-174. Retrieved from https://cdn.salaamgateway.com/specialcoverage/sgie19-20/full-report.pdf

DinarStandard. (2020). State of the Global Islamic Economy Report 2020/21. Dubai International Financial Centre, 112. Retrieved from https://haladinar.io/hdn/doc/report2018.pdf

Eid, R., \& El-Gohary, H. (2015). The role of Islamic religiosity on the relationship between perceived value and tourist satisfaction. Tourism Management. https://doi.org/10.1016/j.tourman.2014.08.003

El-Gohary, H. (2016). Halal tourism, is it really Halal? Tourism Management Perspectives, 19, 124-130.

Fahimnia, B., Tang, C. S., Davarzani, H., \& Sarkis, J. (2015). Quantitative models for managing supply chain risks: A review. European Journal of Operational Research, 247(1), 1-15. https://doi.org/10.1016/j.ejor.2015.04.034

Han, H., Al-Ansi, A., Olya, H. G. T., \& Kim, W. (2019). Exploring halal-friendly destination attributes in South Korea: Perceptions and behaviors of Muslim travelers toward a non-Muslim destination. Tourism Management. https://doi.org/10.1016/j.tourman.2018.10.010

Harahsheh, S., Haddad, R., \& Alshorman, M. (2019). Implications of marketing Jordan as a Halal tourism destination. Journal of Islamic Marketing. https://doi.org/10.1108/JIMA-02-2018-0036

Jafari, J., \& Scott, N. (2014). Muslim world and its tourisms. Annals of Tourism Research, 44(1), 119. https://doi.org/10.1016/j.annals.2013.08.011

Mastercard-Crescentrating. (2016). Global Muslim Travel Index 2016. Crescentrating.Com, (March). Retrieved from https://www.crescentrating.com/reports/masterca rd-crescentrating-global-muslim-travel-indexgmti-2016.html

Mastercard-CrescentRating. (2015). Global Muslim Travel Index 2015. Crescentrating.Com, (March). Retrieved from http://gmti.crescentrating.com/mastercardcrescentrating-global-muslim-travel-index-2015gmti2015.html

Mastercard-CrescentRating. (2017). Global Muslim Travel Index 2017. Crescentrating.Com, (May). Retrieved from https://www.crescentrating.com/reports/masterca rd-crescentrating-global-muslim-travel-indexgmti-2017.html

Mastercard-CrescentRating. (2018a). Global Muslim
Travel Index 2018. Crescentrating.Com, (April). Retrieved from https://www.crescentrating.com/reports/masterca rd-crescentrating-global-muslim-travel-indexgmti-2018.html

Mastercard-CrescentRating. (2018b). Global Muslim Travel Index 2018. Mastercard-Crescentrating.

Mastercard-CrescentRating. (2019). Global Muslim Travel Index 2019. Crescentrating.Com, (April). Retrieved from https://www.crescentrating.com/reports/globalmuslim-travel-index-2019.html

Mastercard-CrescentRating. (2021). Global Muslim Travel Index 2021. Crescentrating.Com, (July). Retrieved from https://www.crescentrating.com/reports/globalmuslim-travel-index-2021.html

Merriam-Webster. (2021). Key word. Retrieved from https://www.merriamwebster.com/dictionary/keyword

Mishra, D., Gunasekaran, A., Papadopoulos, T., \& Hazen, B. (2017). Green supply chain performance measures: A review and bibliometric analysis. Sustainable Production and Consumption, 10, 85-99.

Mohsin, A., Ramli, N., \& Alkhulayfi, B. A. (2016). Halal tourism: Emerging opportunities. Tourism Management Perspectives. https://doi.org/10.1016/j.tmp.2015.12.010

Nik Ramli Nik Abdul Rashid, Chutima Wangbenmad, \& Kamarul Ariffin Mansor. (2021). Halal Tourism: Lessons for Destination Managers of Non-Muslim Majority Countries. International Journal of Business and Society, 21(1), 473-490. https://doi.org/10.33736/ijbs.3264.2020

Papastathopoulos, A., Kaminakis, K., Mertzanis, C., Business, C., Box, P. O., Dhabi, A., \& Emirates, U. A. (2020). What services do Muslim tourists want? Uncovering nonlinear relationships and unobserved heterogeneity. Tourism Management Perspectives, 35 (July), 100720. https://doi.org/10.1016/j.tmp.2020.100720

Rasul, T. (2019). The trends, opportunities and challenges of halal tourism: a systematic literature review. Tourism Recreation Research, 44(4), 434-450.

https://doi.org/10.1080/02508281.2019.1599532

Samori, Z., Md Salleh, N. Z., \& Khalid, M. M. (2016). Current trends on Halal tourism: Cases on selected Asian countries. Tourism Management Perspectives, 19, 131-136. https://doi.org/10.1016/j.tmp.2015.12.011

ScienceDirect. (n.d.). Tourism Management Perspective. Retrieved from https://www.sciencedirect.com/journal/tourism- 
Jurnal Bisnis dan Manajemen, Volume 22, No. 2, September 2021, p. 96-126

management-perspectives/about/aims-and-scope

SCImago. (n.d.). SJR - SCImago Journal \& Country

Rank [Portal]. Retrieved from

https://www.scimagojr.com/

Shah Alam, S., \& Mohamed Sayuti, N. (2011). Applying the Theory of Planned Behavior (TPB) in halal food purchasing. International Journal of Commerce and Management. https://doi.org/10.1108/10569211111111676

Shaharudin, M. S., Fernando, Y., Chiappetta Jabbour, C. J., Sroufe, R., \& Jasmi, M. F. A. (2019). Past, present, and future low carbon supply chain management: A content review using social network analysis. Journal of Cleaner Production, 218 , 629-643. https://doi.org/10.1016/j.jclepro.2019.02.016

Sriprasert, P., Chainin, O., \& Rahman, H. A. (2014). Understanding Behavior and Needs of Halal Tourism in Andaman Gulf of Thailand: A Case of Asian Muslim. Journal of Advanced Management Science, 2(3), 216-219. https://doi.org/10.12720/joams.2.3.216-219

Stephenson, M. L. (2014). Deciphering "Islamic hospitality": Developments, challenges and opportunities. Tourism Management, 40(February 2014), $155-164$. https://doi.org/10.1016/j.tourman.2013.05.002

Tranfield, D., Denyer, D., \& Smart, P. (2003). Towards a Methodology for Developing EvidenceInformed Management Knowledge by Means of Systematic Review. British Journal of Management, 14(3), 207-222. https://doi.org/10.1111/1467-8551.00375

Van Eck, N. J., \& Waltman, L. (2010). Software survey: VOSviewer, a computer program for bibliometric mapping. Scientometrics, 84(2), 523-538. https://doi.org/10.1007/s11192-009-0146-3

Van Eck, N. J., \& Waltman, L. (2013). \{VOSviewer\} manual. Leiden: Univeristeit Leiden, (April). Retrieved from http://www.vosviewer.com/documentation/Manu al_VOSviewer_1.6.1.pdf

Wingett, F., \& Turnbull, S. (2017). Halal holidays: exploring expectations of Muslim-friendly holidays. Journal of Islamic Marketing. https://doi.org/10.1108/JIMA-01-2016-0002

Yagmur, Y., Ehtiyar, R., \& Aksu, A. (2019). Evaluation of halal tourism in terms of bibliometric characteristics. Journal of Islamic Marketing.

Yagmur, Y., Ehtiyar, R., \& Aksu, A. (2020). Evaluation of halal tourism in terms of bibliometric characteristics. Journal of Islamic Marketing, 11(6), 1601-1617. https://doi.org/10.1108/JIMA05-2019-0101. 